九州大学学術情報リポジトリ

Kyushu University Institutional Repository

\title{
THE FAMILY ANTHRIBIDAE OF JAPAN (COLEOPTERA). PART 3
}

Morimoto, Katsura

Entomological Laboratory, Faculty of Agriculture, Kyushu University

https://doi.org/10.5109/2400

出版情報: ESAKIA. 15，pp.11-47，1980-10-31. Entomological Laboratory，Faculty of Agriculture， Kyushu University

バージョン :

権利関係 : 
THE FAMILY ANTHRIBIDAE OF JAPAN (COLEOPTERA). PART $3 *$

\author{
KATSURA Morimoto \\ Entomological Laboratory, Faculty of Agriculture \\ Kyushu University, Fukuoka 812, Japan
}

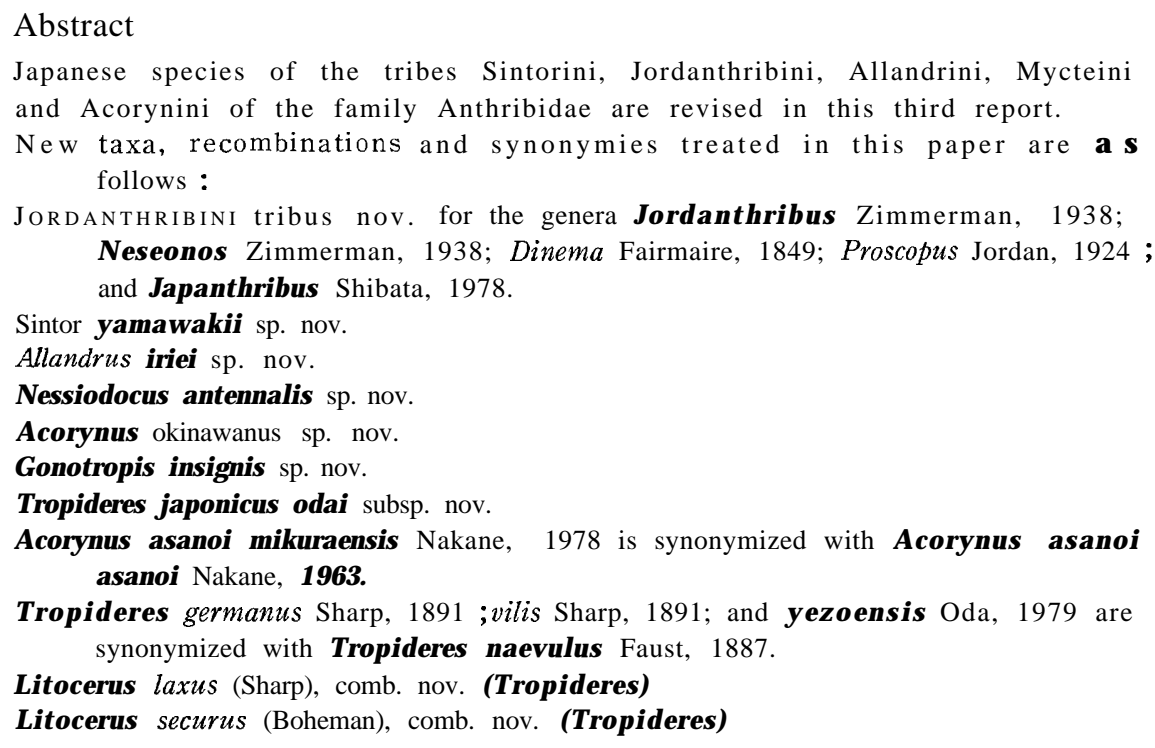

\title{
Tribe SINTORINI
}

Sintorides Lacordaire, Gen. Col., VII: 510, 1966.

Sintorini Morimoto, Bull. Gov. Forest Exp. Sta., 246: 38, 1972.

\section{Sintor S choenherr}

Sintor Schoenherr, Gen. Sp. Curc., V: 148, 1839 (Type : Sintor quadrilineatus Fahraeus, by original designation) ; Lacordaire, Gen. Col., VII: 510, 1866; Shibata, Ent. Rev. Japan, XXII : 12, 1969 (Sintor=Blabirhinus).

Blabirhinus Sharp, Trans. Ent. Soc. London, 1891: 299, 1891. (Type: Blabirhinus dorsalis Sharp, by monotypy).

Sintor dorsalis dorsalis (Sharp) (Fig. 1, A ; Fig. 2, B; Photo. A)

Blabirhinus dorsalis Sharp, Trans. Ent. Soc. London, 1891: 300, 1891 (Higo).

* Contribution from the Entomological Laboratory, Faculty of Agriculture, Kyushu University, Fukuoka (Ser. 3, No. 76). 
Sintor dorsalis dorsalis: Shibata: Ent. Rev. Japan, XXII: 13, pl. 2, fig. 7 \& 8, 1969 (Mt. Hiko ; redescription).

Specimens examined: Mt. Hiko, Fukuoka Pref., $1 \succsim, 12$. vii. 1955, H. Kamiya leg. ; 1 ㅇ, 2. vi. 1958, K. Morimoto leg. Mt. Hōman, Fukuoka Pref., $1 \precsim$, 23. v. 1973, H. Irie leg. Fukakurakyo, Fukuoka Pref., 1 ๙, 15. ix. 1971, H. Irie leg. Mt. Kumado, Fukuoka Pref., 1 우, 30. vi. 1957, H. Ishibashi leg.

Distribution : Japan (Kyushu).

Sintor dorsalis intermedius Shibata (Fig. 1, B; Photo. B)

Sintor dorsalis intermedius Shibata, Ent. Rev. Japan, XXII: 14, pl. 2, fig. 9, 1969 (Is. Tsushima: Nasu pass) ; Shibata, Ent. Rev. Japan, XXXI: 25, 1978 (Taiwan ; redescription).

Specimens examined: Kikokuyama, Tsushima, 1 우, 18. v. 1971, H. Irie leg. Wulai, Taiwan, 1 우, 27. v. 1976, Y. Miyatake leg. Liyuchih, Hualien Hs., Taiwan, $1 \delta$, 14. viii. 1966, H. Sasaji leg. Hungyeh Wenchuan, Hualien Hs., Taiwan, 18, 13. vi. 1976, H. Makihara leg.

Distribution : Japan (Tsushima), Taiwan.

Note. This subspecies was originally described from Is. Tsushima based on a single male and recorded from Taiwan by Shibata (1969, 78), who gave the subspecific characters as "The dorsal carina of pronotum not angulate or weakly produced backward in the middle and the basal margin of elytra more uneven, well prominent forward near scutellum". With the courtesy of $\mathrm{Mr}$. H. Irie, I could examine a female from Mt. Kikokuyama, Tsushima, which fits exactly with the original description of intermedius. Out of five specimens from Fukuoka Pref., one male has the straight dorsal carina on the pronotum as intermedius, but the scaly pattern is the same as dorsalis dorsalis. Three specimens from Taiwan before me have straight dorsal carina as noted by Shibata. For the insufficiency of materials, I can not give any satisfactory resolution on the subspecies problem, but the following notes:

dorsalis dorsalis from Fukuoka Pref. : The blackish bands on the declivity of the $3 r d$ to 7 th intervals of elytra not broken; the dorsal carina of pronoturn angulate or straight.

dorsalis intermedius from Tsushima: The transverse black bands on the decliv-

ity of the 3rd to 7 th intervals broken into small spots on 3rd, 5th and 7th intervals; the dorsal carina of pronotum straight.

dorsalis intermedius from Taiwan: The transverse black bands on declivity as in dorsalis dorsalis; the dorsal carina of pronotum straight.

Sintor bipunctatus Shibata (Photo. F)

Sintor bipunctatus Shibata, Ent. Rev. Japan, XXII: 14, pl. 2, fig. 5 \& 6, 1969 (Is. Yaku, Is. Nakanoshima, Is. Amami).

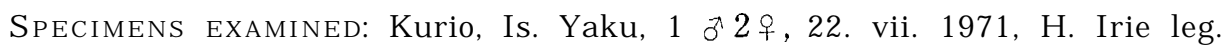
Miyanoura, Is. Yaku, 1 우, 15. vii. 1973, H. Irie leg. ; 1 우, 17. vii. 1974, H. Irie leg. Shiratani, Is. Yaku, 2 ㄱ1우, 6-7. v. 1972, H. Irie leg. ;1우, 10. vii. 1973, H. Irie leg. Ōkawa, Is. Yaku, 1 우, 2. viii, 1974, K. Sugino leg. Is. Nakanoshima, 
Tokaras, 1 § 3 우, 4. iv. 1974, H. Irie leg.; 1 § 1 ㅇ, 25. iv. 1975, H. Irie leg. Hatsuno, Is. Amami-Oshima, 2 ð, 2 \& 6. vii. 1970, H. Irie leg. Shinmura, Is. Amami-Oshima, $1 \precsim$, 8. iv. 1977, T. Ogasawara leg.

Distribution: Japan (Is. Yaku, Is. Nakanoshima, Is. Amami-Oshima).

Sintor yamawakii sp. nov. (Fig. 1, C-D; Photo. C-E)

Derm brown, rostrum and mandibles dark brown, densely covered with greyish and pale brownish grey pubescence ; the latter forming a pair of short admedian stripes on head, two pairs of admedian and latero-ventral stripes on prothorax, evenly covering the even-numbered intervals of elytra, also forming terminal and 3-4 additional spots on each tibia, and a spot on median and hind femora; scutellum covered with whitish pubescence; elytra with oddnumbered intervals indistinctly mottled with greyish and pale brownish grey spots, with a pair of blackish velvety stripes from about the middle of 3rd interval obliquely backwards to 7 th interval; blackish pubescence forming a few small spots on odd-numbered intervals of elytra and admedian stripes on pronotum, number and position variable, often the black spots arranged transversely on $3 \mathrm{rd}$, 5th and 7 th intervals on declivity of elytra. Underside evenly covered with greyish pubescence with brownish grey antero-lateral corners on 2 nd to 4 th ventrites and lateral margins of 5 th ventrites.

Rostrum thick and apically slightly widened, length from the anterior margin of eye to the base of labrum: maximum width below the antenna1 insertion $=3: 2$ in male or $4: 3$ in female, broadly impressed above, the impression

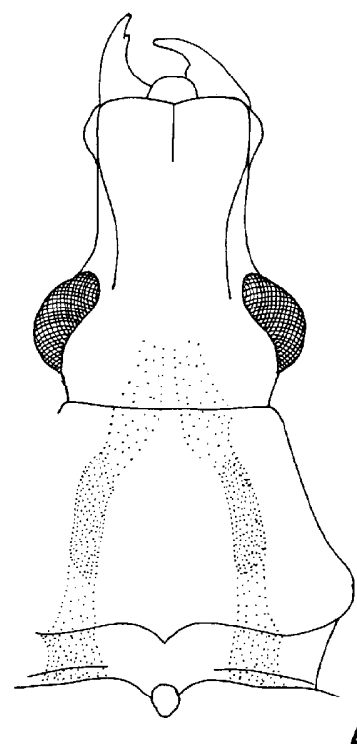

A

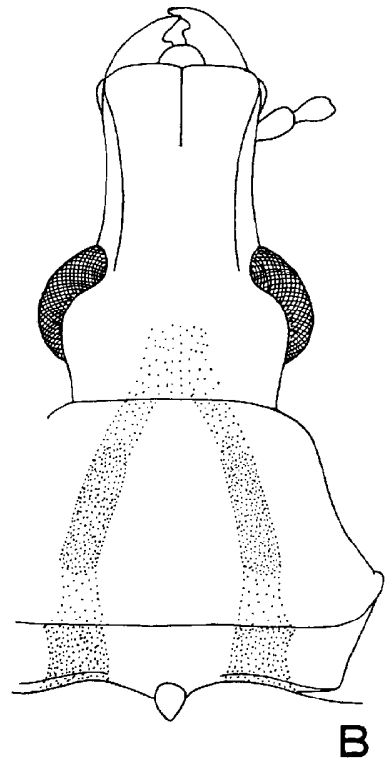

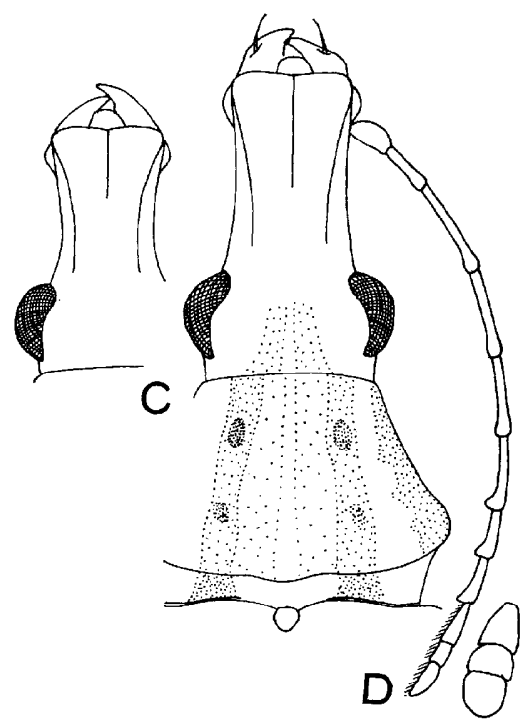

Fig. 1. Sintor spp. (A :dorsalis dorsalis, Fukakurakyo. B :dorsalis intermedius, Tsushima. C, D: yamawakii, C: female, D : holotype, male). 
being bounded on each side by a subcariniform ridge, the ridges slightly convergent towards the middle posteriorly from the anterolateral corners of rostrum and ending at the base of rostrum just between the anterior margin of eyes, median carina distinct on the anterior half. Antennae in male reaching posteriorly well beyond humeri, with proportions in length measured along mesial line $6: 10: 17: 15: 14: 12: 10: 7: 6: 4: 7$, width of club $7.5(20=1 \mathrm{~mm})$; 2nd-5th segments thick at apex, 6th to 8th segments triangularly expanding ventrally at apex, club weakly convex dorsally and flat ventrally with suberect setae; in female, antennae scarcely exceeding posteriorly beyond humeri, with proportions in length $6: 9: 11: 8: 7: 6: 5: 4: 7: 4: 9$, width of 8 th 3 , club 8 $(30=1 \mathrm{~mm})$, 2nd-6th segments thick at apex, 7 th and 8 th segments subconical, club without suberect setae on the underside.

Pronotum almost twice as wide before the base as at the apex, dorsal carina indistinctly produced backwards in a small arc at the middle and broadly rounded on each side, carinulae distinct.

Scutellum a little broader than long, subtriangular.

Elytra weakly convex basally between scutellar and 4th striae, 1st and 2nd intervals flat behind the humps, weakly depressed at the base of 5 th intervals.

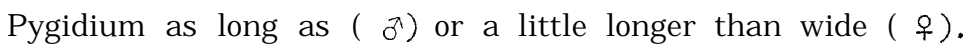

Undersurface of head and rostrum before glossy base, and lateral and ventral surface punctate and sparsely pubescent.

Length : 8.5-10 $\mathrm{mm}$ (incl, rostrum), 6.1-7.3 $\mathrm{mm}$ (excl. rostrum).

Holotype ð (Type No. 2193, Kyushu Univ.), Hoshino, Is. Ishigaki, 26. vi. 1970, Y. Yamawaki leg.

Paratypes: $2 \jmath^{\top} 1$ 우, same data as holotype. 1 우, Arakawa, Is. Ishigaki, 16. vi. 1972, H. Irie leg.

Distribution: Japan (Is. Okinawa ?, Is. Ishigaki).

I have examined one male from Yona, Is. Okinawa (9. vi. 1977, H. Irie leg.). This male is seemed to be conspecific with the present new species, but is a little smaller $(7.2 \mathrm{~mm}$ incl. rostrum, or $5.4 \mathrm{~mm}$ to the anterior margin of pronotum), and darker in pubescent coloration.

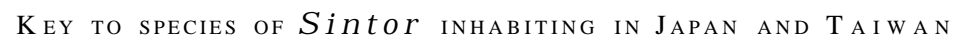

1 : Tarsi with the 1 st segment as long as 2 nd and 3 rd combined; rostrum with a median carina; elytra with a transverse broad M-shaped black band behind

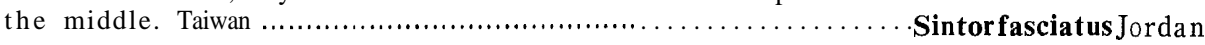

1' : Tarsi with the 1 st segment longer than 2 nd and 3 rd combined; rostrum with

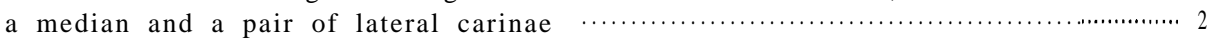

2 : Antennae with loose club, elytra with tubercles, pubescence dusky ochreous, with a conjoint reverse $\mathrm{V}$-shaped black mark at the middle of elytra. Taiwan

2': Antennae with compact club, elytra not tuberculate, elytra with a pair of oblique band from the middle of 3 rd interval obliquely backwards to 7 th in- 
terval.

3 : Body length up to $5 \mathrm{~mm}$ (pronotum plus elytra), rostrum a little longer than wide, oblique bands narrow. Japan and Taiwan ................ Sintor dorsalis (Sharp)

3' : Body length more than $5.5 \mathrm{~mm}$, rostrum much longer than wide, oblique bands wider

4 : Latero-ventral and ventral surface of head and rostrum between scrobes and eyes sparsely with dark brown fine pubescence, median blackish patches on elytra larger and rhombiform, general coloration of pubescence brown or reddish brown. Is. Yakushima, Is. Nakanoshima, Is. Amami-Oshima

Sintor bipunctatus Shibata

4': Latero-ventral surface of head and rostrum with greyish pubescence, median patches on elytra narrower, general coloration of pubescence greyish and pale brownish grey. Is. Okinawa ?, Is. Ishigaki ..................... Sintor yamawakii sp. nov.

\section{Asemorhinus Sharp}

A semorhinus Sharp, Trans. Ent. Soc. London, 1891: 298, 1891 (Type-species : A semorhinus nebulosus Sharp, by monotypy)

Asemorhinus nebulosus Sharp (Fig. 2, A; Photo. G)

A semorhinus nebulosus Sharp, Trans. Ent. Soc. London, 1891: 299, 1891 (Hara, Yuyama) ; Jordan, Novit. Zool., XIX: 144, 1912 (Formosa) ; Nakane, Icon. Ins. Jap. col. nat. ed., II: 350, pl. 175, fig. 24, 1963 (Honshu, Kyushu, Is. Nakanoshima, Taiwan).

Specimens examined: 74 exs. from Amakusa, Is. Nakanoshima, Is. Ishigaki, Is. Iriomote, and Taiwan.

Distribution: Japan (Honshu, Kyushu, Is. Nakanoshima, Is. Ishigaki. Is. Iriomote), Taiwan.
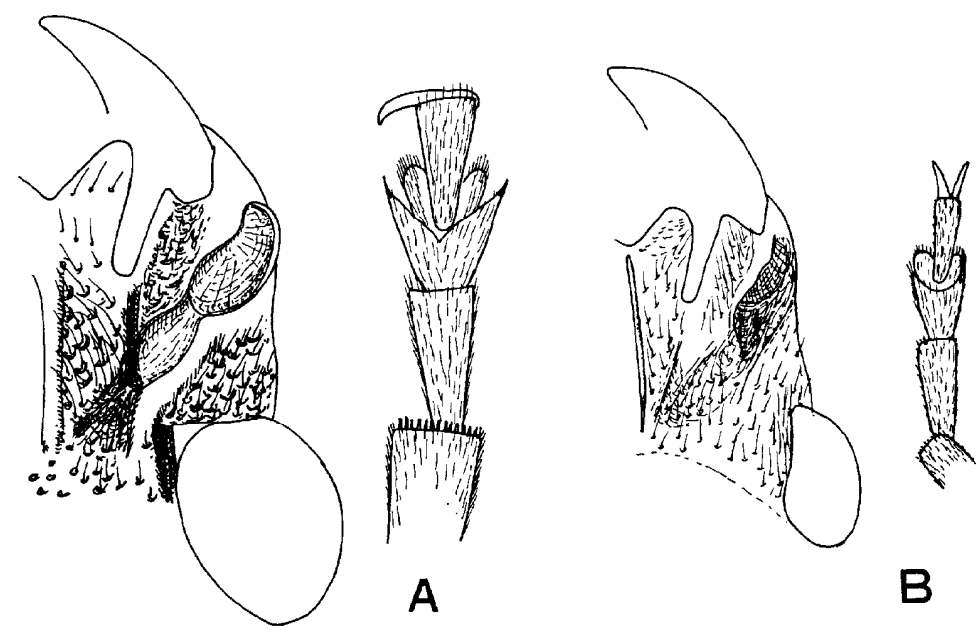

Fig. 2. Rostrum, ventro-lateral aspect showing scrobes, and right front tarsus. (A : Asemorhinus nebulosus. B : Sintor dorsalis). 


\section{Tribe Jordanthribini nov.}

Proscopus-Neseonos-Jordanthribus complex, Zimmerman, Occ. Pap. Bishop Mus., XIV : 233, 1938.

Rostrum and frons vertical, forming an angle with occiput. Eyes emarginate. Antennae inserted on head, either on the inner sides of eyes near their tops or at the lower margin of eyes, with a distinct tuberculiform callosity above scrobe, 1st segment much longer than 2nd. Dorsal prothoracic carina antebasal, curving forwards at side.

Type-genus :Tordanthribus Zimmerman, 1938.

Included genera : Neseonos Zimmerman, 1938 ; Dinema Fairmaire, 1849 ; Proscopus Jordan, 1924 ; and Japanthribus Shibata, 1978.

Distribution: Polynesia and Micronesia.

\section{Japanthribus Shibata}

Japanthribus Shibata, Entom. Rev. Japan, XXXI: 99, 1978. (Type-species : Japanthribus kusuii Shibata, by original designation).

The present genus is very close to Jordanthribus, but the eyes are much smaller.

Japanthribus kusuii Shibata (Fig. 3)

Japanthribus kusuii Shibata, Ent. Rev. Japan, XXXI: 100, 1978 (Is. Hahajima; female).

Male. Derm yellow, shiny; eyes black; frons and pronotum with dark area at middle ; elytra with several dark patches; pubescence whitish on yellowish area and dark brownish on dark patches; long hairs on the sharp edge between frons and occiput blackish.

Head finely punctate and setose; frons flattened and forming a sharp angle with occiput, with long erect hairs on the angle, the hairs closer on each side and at the middle; rostrum flat and forming a perfectly flat surface with frons from vertex to apex, with a pair of fine carinae dividing sides from flat dorsum running from inner margins of eyes to apex, dorsum closely with fine punctures and pubescent, side margins of head and rostrum continuously concave, the narrowest breadth about half the maximum apical breadth. Antennae with 1 st segment as long as three following segments combined, curved at base and clavate at tip, with long setae at apex, 2nd to 8th segments slender, weakly clavate, 2nd a little longer than lst, weakly curved, 4th to 7th subequal in length, 8th a little shorter than 7 th, 9th to 11 th slightly broader than 8th, 9th as long as llth, 10th a little shorter than 9th.

Pronotum transverse, about twice as broad as long, the sides rounded, broadest at basal third; dorsal carina brown, very finely serrate, continuously curved latero-anteriorly to form a lateral carina, that reaches a little past the middle of the sides; posterior margin with a row of brown dots in a manner of dotted line; disc densely and minutely punctate, pubescence anteriorly inclined. 


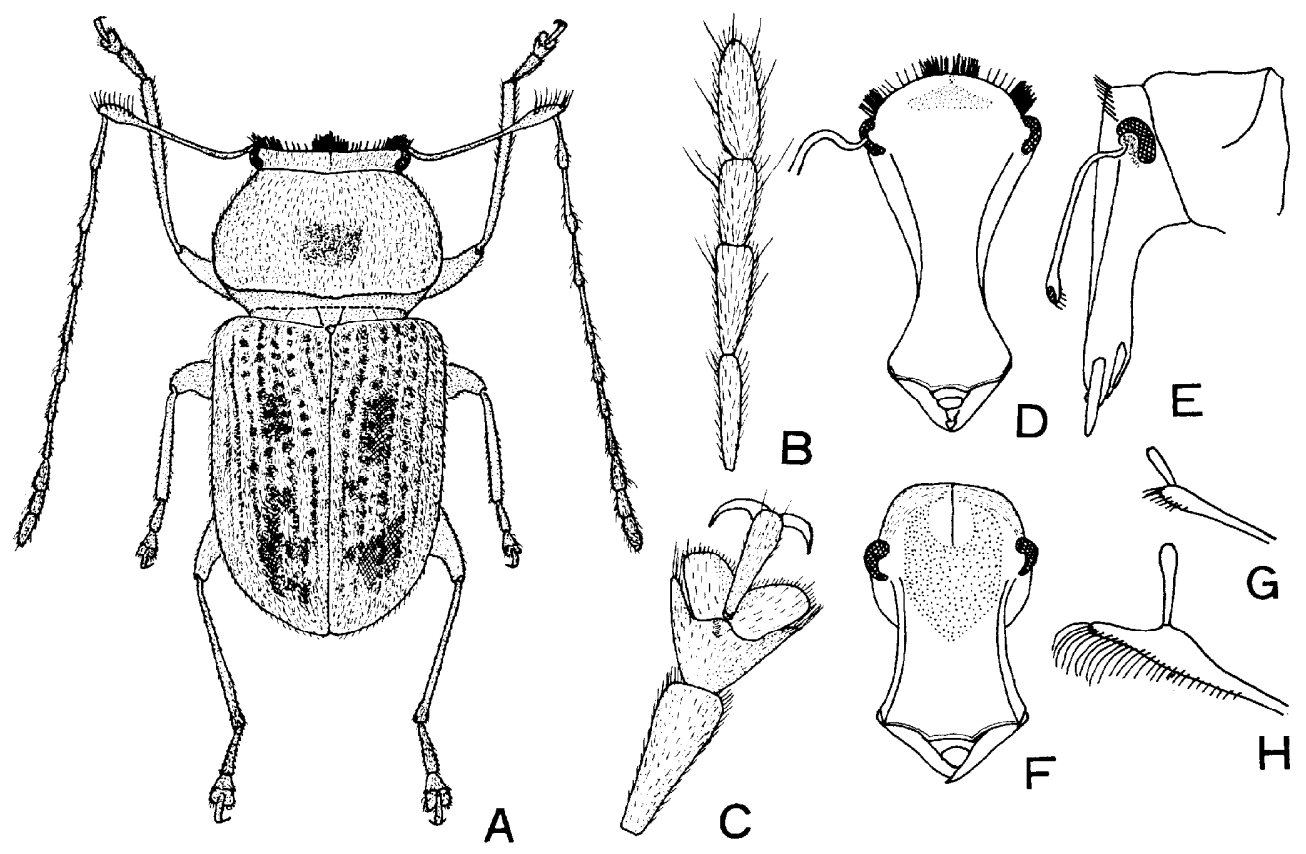

Fig. 3. Japanthribuskusuii. (A: Male. B: Male antenna1 club. C: Male front tarsus. D, E: Male head. F: Female head. G, H: Apex of first segment of antenna in male showing variation).

Elytra longer than wide $(4: 3)$, parallel-sided from subtruncate base to apical declivity, shallowly punctate-striate ; intervals narrower than striae, inpunctate ; pubescence hair-like, whitish pubescence forming several condensed areas.

Legs with fore femora thicker than the others, 1st segment of tarsi about twice as long as wide, 2nd segment transverse. Underside finely and shallowly punctate, shortly and sparsely hairy. Pygidium broader than long (11 : 9), minutely punctate, sparsely hairy as on elytra.

Female. Head with frons forming a rounded, obtuse angle with occiput, with several long and anteriorly directed hairs on the angle at middle; rostrum weakly concave at sides, the narrowest breadth $7 / 9$ the maximum breadth at apex; antennae with 1 st segment weakly curved, not adorned with long setae.

Length :2.7-3.0 mm.

Spectmens examined : Okimura, Is. Hahajima, 2 우, 4. vi. 1975, T. Seino leg. Hyogitaira, Is. Hahajima, $1 \delta 1$ Q, 21. vi. 1976, H. Irie leg. Kitamura, Is. Hahajima, 2 o 2 Q, 24-26. vi. 1976, H. Irie leg. Komoridani, Is. Hahajima, 1 ð 2 Q, 6. vii. 1976, H. Irie leg. Nakanodaira, Is. Hahajima, 1 §3 Q, 5. vii. 1976, H. Irie leg. Ōmura, Is. Chichijima, 1 ð, 19. vi. 1976, H. Irie leg. Mikazukiyama, Is. Chichijima, 1 đ 2 오, 12 . vi. 1976 , T. Nakane leg. 
Distribution: Japan (Ogasawara Isls.: Is. Chichijima and Hahajima).

Note. This species is considerably variable in the coloration of head, pronotum and elytra. The head is usually with a dark median patch of various size in specimens, but often the patch is obsolete and concolorous. The pronotum is usually with a dark median patch, but in some specimens has an additional dark patches on each side. The elytra is almost concolorous except for dark band on declivity, or with several dark patches, or variegated with brownish black patched.

\section{Tribe Allandrini}

Allandrini Pierce, Proc. U. S. Nat. Mus., 77, Art. 17: 18, 1930; Valentine, Trans. Amer. Ent. Soc., LXXXVI: 49, 1960; Morimoto, Bull. Gov. Forest Exp. Sta., 246: 41, 1972.

\section{Key to genera of Allandrini occurring in Japan}

1 : Eyes oblong-oval ; tarsi with the 1st segment as long as (q) or longer than (o) the remaining segments taken together.......................... Plintheria Pascoe

1': Eyes lateral, rounded; tarsi with the 1st segment more or less shorter than

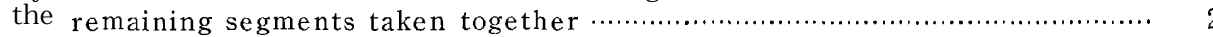

2 : Frons between eyes wider than the minimum width of rostrum, tarsi with the 1st segment nearly as long as 2nd and 3rd combined, claws unarmed...

Allandrus LeConte

2' : Frons between eyes narrower than rostrum; tarsi with the 1st segment much longer than 2nd and 3rd taken together, claws armed …........Endreytes Schoenherr

\section{Allandrus LeConte}

Allandrus LeConte, Proc. Am. Phil. Soc., XV: 396, 1876. (Type-species: Allandrus bifasciatus LeConte, by monotypy).

\section{Allandrus iriei sp. nov. (Fig. 4)}

Female. Black, legs and elytra chestnut brown, with whitish pubescence sparse on each side of head along inner margin of eye, and arranged in sparse stripes on pronotum, the median stripe denser before scutellum and apex, the lateral stripes denser at Iatero-posterior corners; elytra with two whitish fasciae, anterior fascia at basal third and extends forwards on 1 st interval to the base and widening posteriorly to the side, the postmedian band at apical third, apex with whitish patch; underside of head with a few whitish pubescence beside eyes, underside of thorax and coxae with whitish pubescence, venter with fine brownish grey pubescence, which is smaller and shorter than those on thoracic sterna.

Head reticulately punctate, frons between eyes wider than the minimum width of rostrum; eyes lateral, convex, rounded; rostrum longer than head, strongly narrowed behind antenna1 scrobes, apex wider, flat above, irregularly and densely punctate, the punctures smaller than those on head, with a trace of median carina. Antennae not reaching the base of pronotum, with proportions in Iength from base $9: 12: 12: 9: 7: 7: 7: 7: 12: 8: 13$, width of 1 st 5 , 2nd 7 , 3rd 5 , 8th 6 , 9th 11 , 10th 13 , 11th $12(100=1 \mathrm{~mm})$. 

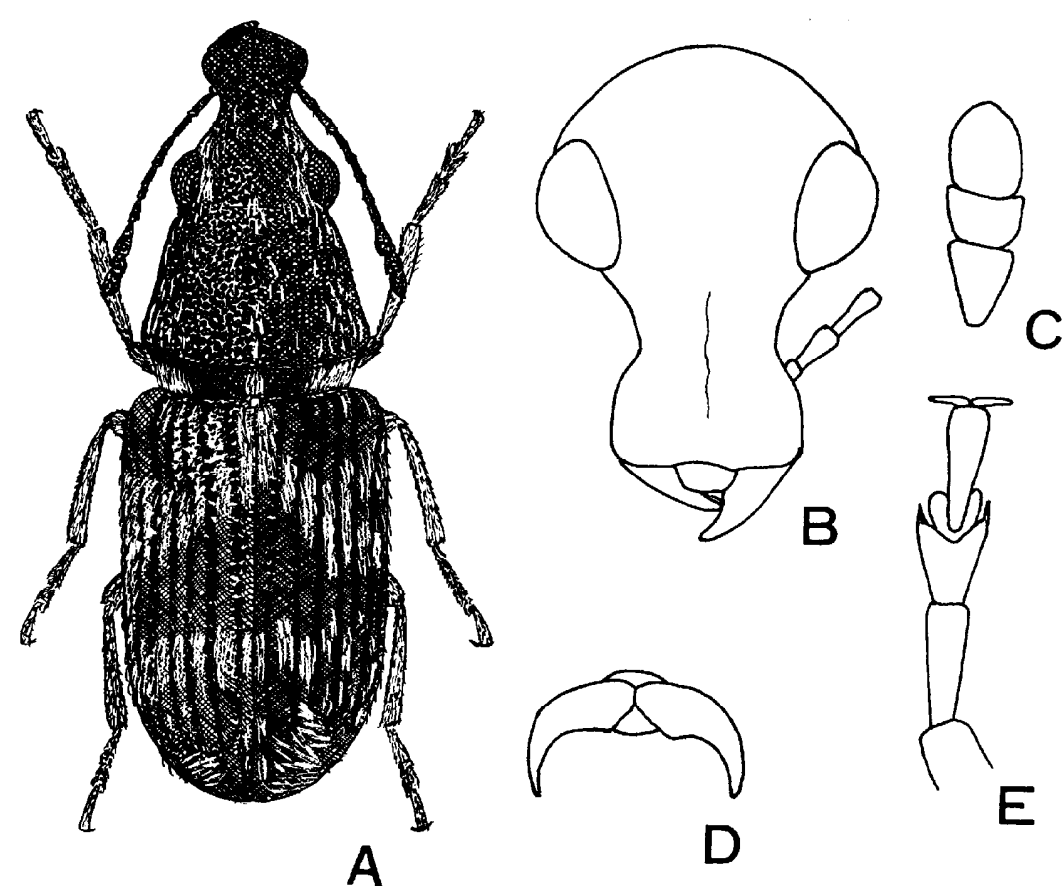

D

Fig. 4. Allandrus iriei sp. nov. (A: Holotype B: Head. C: Antenna1 club. D: Tarsal claw. E: Right front tarsus).

Pronotum broader than long (9:7), broadest at basal third and straightly narrowing anteriorly, apical margin slightly narrower than basal margin, disc reticulately punctate as on head, transverse carina weakly sinuate, curving roundly into a short lateral carina on each side.

Scutellum small, rounded, densely covered with white pubescence.

Elytra parallel-sided, basal margin slightly concave, striae with deep and close punctures, intervals much wider than striae, flat with fine granules.

Legs with femora clavate; tibiae weakly expanding toward apex; tarsi with 1st segment slightly longer than 2nd and 3rd combined, 2nd segment a little longer than wide, claws strongly divergent, unarmed. Underside of rostrum with a median carina.

Length : $2.5 \mathrm{~mm}$ (excl. head).

Holotype 우 (Type No. 2194, Kyushu Univ.), Kiyosato, Ikutabara-cho, Hokkaido, 28. vii. 1976, H. Irie leg.

Distribution : Japan (Hokkaido).

This small new species is similar to A. populi Pierce, but the shape of pronotum is different in comparison with the illustration by Pierce (1930).

Endreytes Schoenherr

Endreytes Schoenherr, Gen. Curc., V: 215, 1839. (Type-species : Endreytes hilaris Fahrakus, by original designation). 
Endreutes Lacordaire, Gen. Col., VII: 536, 1866.

Endreytes gotoi Shibata (Fig. 5, A-D; Photo. J)

Endreytes gotoi Shibata, Ent. Rev. Japan, XXII: 28, pl. 4, fig. 7 \& 8, 1969 (Sasabe, Nose, Hyogo Pref. ; Senriyama, Osaka).

Specimens examined: Mt. Hiko, Fukuoka Pref., $1 \precsim, 31$. vi. 1974, H. Irie leg. Tatsudayama, Kumamoto City, 18, 31. v. 1977, K. Morimoto leg. ; 2 우, 2. vii. 1977, K. Morimoto leg.; 1 đ , 5. vii. 1977, K. Morimoto leg.

DistRibution : Japan (Honshu, Kyushu) .

\section{Endreytes sp. 1}

Specimen examined: Shirahama, Is. Iriomote, $1 \precsim$, 5. iv. 1974, H. Irie leg.

This species is very close to gotoi, but the punctuation on pronotum is weaker.

\section{Endreytes sp. 2}

Specimen EXAmined: Ichinohashi, Shimokawa-cho, Hokkaido, 1 ð, 26. vii. 1976, H. Irie leg.

This is also very close to gotoi, but the pronotum is weakly narrowing anteriorly and elytra are a little narrower

\section{Plintheria Pascoe}

Plintheria Pascoe, Ann. Mag. Nat. Hist., (3) IV: 435, 1859. (Type-species : Plintheria luctuosa Pascoe, by monotypy).

Plintheria variolosa Shibata (Fig. 5, E-G; Photo. I)

Plintheria variolosa Shibata, Ent. Rev. Japan, XXII: 26, pl. 4, fig. 6, 1969 (Is. Amami, Is.

Nakanoshima, Is. Yaku, Kagoshima City).

Spectmens examined: Mt. Yuwandake, Is. Amami-Oshima, 6 ð3 1963, Y. Hirashima \& J. L. Gressitt leg. Hatsuno, Is. Amami-Oshima, 1 우, 3. vi. 1962 , M. Sato leg. ; 1 우, 28. vi. 1970, H. Irie leg.; 1 1 우, 3. vii. 1970, H. Irie leg. ; 1 우, 3. vii. 1972, H. Irie leg. Shinmura, Is. Amami-Oshima, $1 \overbrace{}^{\top} 1$ 우, 19. vii. 1954, S. Hisamatsu leg. Nishinakama, Is. Amami-Oshima, 1 우, 1-7. vi. 1970, H.
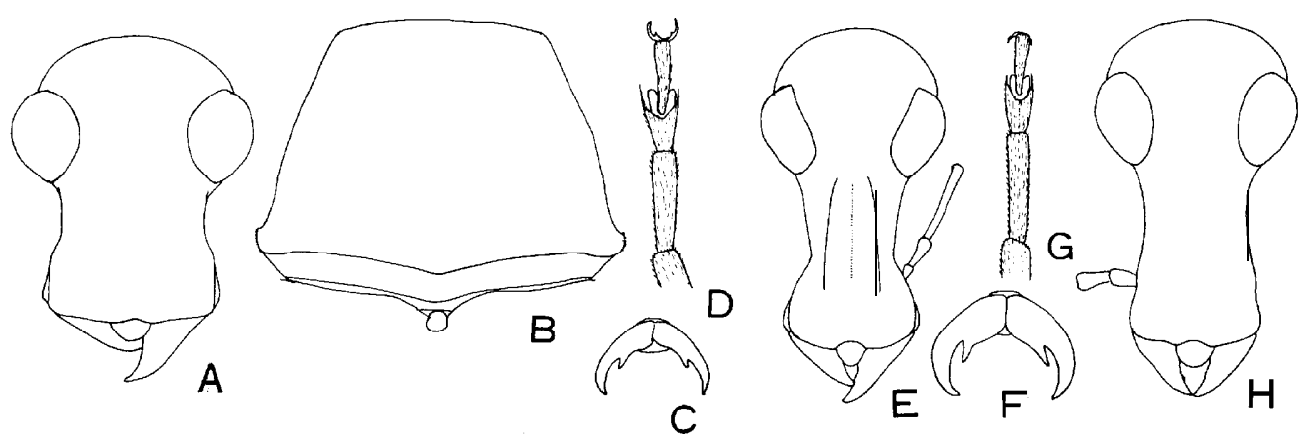

Fig. 5. A-D : Endreytes gotoi (A: Male head. B: Pronotum. C: Tarsal claw. D: Right front tarsus). E-G: Plintheria variolosa (E: Male head. F: Tarsal claw. G: Right front tarsus). $\mathrm{H}$ : Plintheria caliginosa, male head. 
Makihara leg. Is. Nakanoshima, Tokaras, 1 ð 우, 1-2. vii. 1973, H. Irie leg. Mt. Ariakeyama, Izuhara, Tsushima, 1 ㅇ, vii. 1978, H. Irie leg.

Distribution: Japan (Kagoshima City, Tsushima, Is. Yaku, Is. Nakano. shima, Is. Amami-Oshima).

Plintheria caliginosa Shibata (Fig. 5, H; Photo. H)

Plintheria caliginosa Shibata, Ent. Rev. Japan, XXXIV : 39, fig. 1, 1980 (Chichijima ; male).

SPecimens exAmined : Okimura, Is. Hahajima, $2 \precsim 2$ \%, 4. vi. 1975, T. Seino leg. Hyogitaira, Is. Hahajima, 1 ㅇ, 6. vi. 1973, H. Fujita leg.; 1 ð 1 ㅇ, 22 . vi. 1976, Y. Kurosawa leg. Mt. Chūō, Is. Chichijima, 1 우, 20. vi. 1975, T. Seino leg. Mt. Mikazuki, Is. Chichijima, 1 ㅇ, 30. v. 1975, T. Seino leg.

Distribution : Japan (Ogasawara Isls.: Is. Chichijima and Hahajima).

Note. This species is very characteristic among species of the genus Plintheria so far described in having the flat rostrum without carinae and abbreviate median carina on the underside of rostrum, where the weak carina is discernible only on the labiophore.

\section{Tribe M ycteini}

M ycteini Morimoto, Bull. Gov. Forest Exp. Sta., 246: 41, 1972.

Rostrum narrower than head at base, much longer than wide, flattened dorso-ventrally, lateral margin not carinate, head and rostrum forming continuous arc at side; eyes oblong-oval ; antennae with slender and three-segmented clubs, antenna1 scrobes latero-ventral, about the middle of rostrum in position.

Pronotum broader than long, with a transverse depression before the middle, dorsal carina antebasal. Mesosternal process broad, truncate.

This tribe is close to Acorynini, but the rostrum is much longer, 1st segment of antennae is much longer than the 2nd, especially in male, and the undersurface of head is continuous to rostrum forming an arc in profile,

\section{Sympaector Kirsch}

Sympaector Kirsch, Mitt. Mus. Dresden, I: 52, 1875. (Type-species: Sympaector vittifrons Kirsch, by monotypy).

Sympaector rugirostris (Sharp) (Fig. 6; Photo. M)

Tropideres rugirostris Sharp, Trans. Ent. Soc. London, 1891: 302. 1891 (Nikko, Chuzenji, Jun-

sai); Nakane, Icon. Ins. Jap. col. nat. ed., II : 352, 1963, pl. 176, fig. 17, 1963 (Honshu,

Shikoku) ; Shibata, Ent. Rev. Japan, XXII: 20, 1969.

Sympaector rugirostris: Shibata, Ent. Rev. Japan, XXXI : 93, 1978,

Rostrum much longer than wide, flattened, rugose, with a median and latero-median carinae behind antenna1 insertions, lateral carina absent, the sides continuously forming arc from head and narrowing anteriorly to the middle and widening apically; eyes oval, convergent on frons; antennae reaching behind the middle $\left(a^{\prime}\right)$ or behind humeri $(q)$ of elytra, club slender. 

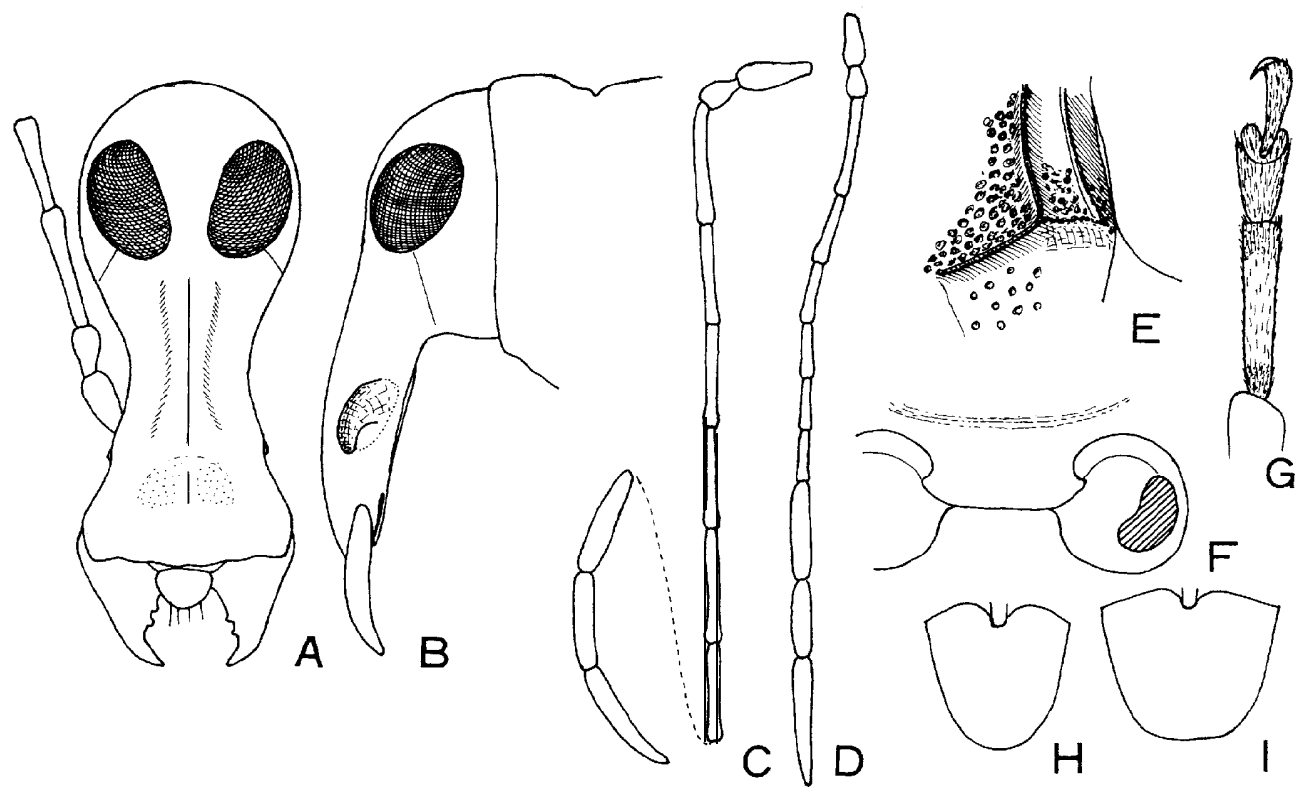

Fig. 6. Sympaector rugirostris. (A, B: Male head. C: Male antenna. D: Female antenna. E: Hind angle of pronotum, lateral aspect. F: Mesosternal process. G: Right front tarsus, male. H: Male pygidium. I: Female pygidium).

Pronotum with transverse median sulcus, dorsal carina almost straight, lateral carina reaching to the middle, carinulae distinct. Elytra weakly arched and marginate at base.

Mesosternal process wide, subtruncate. First ventrite with a short median carina in male. Tarsi with 1 st segment a little longer than the remaining segments taken together.

Specimens examined: Hirakubo, Hinoemata, Fukushima Pref., 1 우, 8. viii. 1976, H. Irie leg. Mt. Sobo-Obira, Öita Pref., 1 ð' '24. vii. 1970, A. Nagatomi leg. Mt. Aoidake, Miyazaki Pref., $1 \delta^{\tau}, 3$. viii. 1974, K. Morimoto leg. Mt. Takachihonomine, Kagoshima Pref., $1 \precsim$, 22. vii. 1933, Hori \& Fujino leg. Shiratani, Is. Yaku, 1 ㅇ , 7. v. 1972, H. Irie leg.

DistRIBUtion: Japan (Hokkaido, Honshu, Shikoku, Kyushu, Is. Yaku).

Note. This species is easily separable from the other species of Sympaector except for crassicornis Jordan by the shorter antennae.

\section{Tribe ACORYNINI}

Acorynides Lacordaire, Gen. Col., VII: 512, 1866.

Acorynini Morimoto, Bull. Gov. Forest Exp. Sta., 246: 37, 1972.

Tropiderini LeConte, Proc. Amer. Phil. Soc., XV: 392, 1875 (partim); Valentine, Trans. Amer. Ent. Soc., LXXXVI: 49, 1960.

Eurymycterini Pierce, Proc. U. S. Nat. Mus., 77, Art. 17: 15. 1930. 


\section{Nessiodocus Heller}

Nessiodocus Heller, Ent. Blätt., 21: 106, 1925 (Type-species: Nessiodocus jordani Heller, by original designation).

Nessiodocus triodes (Jordan) (Fig. 7, A-C; Photo. N)

Mucronianus triodes Jordan, Novit. Zool., XIX : 140, 1912 (Formosa).

Nessiodocus triodes: Jordan, Novit. Zool., XXXIV: 85, 1928; Shibata, Ent. Rev. Japan, XXII: 23, pl. 4, fig. 2, 1969 (Is. Yaku, Is. Amami, Nara; redescription) ; Shibata, Ent. Rev. Japan, XXXIV: 22, 23, pl. 2, figs. 7-9, 1980 (Key; Taiwan).

Specimens examined: Mt. Kirishima, Kagoshima Pref .,1 1 ㅇ, 2. viii. 1959, H. Maebara leg. Anbō, Is. Yaku, 1 우, 11. vii. 1973, H. Irie leg. Mt. Yonahada. ke, Is. Okinawa, 1 , 24. iv. 1973, H. Irie leg. Yona, Is. Okinawa, $1 \delta^{\star}, 4$. vi. 1974, H. Irie leg. Shirahama, Is. Iriomote, 1 우, 11. vi. 1972, H. Irie leg. Nakara Riv., Is. Iriomote, 1 ㅇ, 25-28. vi. 1970, H. Makihara leg. Urai, Taipei Hs., Taiwan, $1 \precsim$ 27. vi. 1976, H. Makihara leg. Kenting-park, Pingtum Hs., $1 \delta^{\jmath} 1$ 우, 3. v. 1971, K. Sakai leg. Mt. Shihtoushan, Miaoli Hs., Taiwan, 1 우, 4. vi. 1976, H. Makihara leg. Nanshanchi, Nantou Hs., Taiwan, 1 ๙, 16. v. 1971, K. Sakai leg.

Distribution: Japan (Honshu, Kyushu, Is. Yaku, Is. Amami-Oshima, Is. Okinawa, Is. Iriomote), Taiwan.

Nessiodocus repandus (Jordan) (Fig. 7, D-F ; Photo. 0)

Mucronianus (3) repandus Jordan, Novit. Zool., XIX : 141, 1912 (Formosa: Fuhosho; female). Nessiodocus repandus : Shibata, Ent. Rev. Japan, XXII: 24, pI. 4, fig. 3, 1969 (Is. Yaku, Nara; redescription) ; Shibata, Ent. Rev. Japan, XXXIV: 22, 26, pl. 2, figs. 1-3, 1980 (Key ;=latefasciatus; Taiwan).

Tropideres latefasciatus Nakane, Fragm. Col., (8) : 33, fig. 4, 1963 (Sata, Mt. Katamuki) ; Nakane, Icon. Ins. Jap. col. nat. ed., II: 352, pl. 176, fig. 20, 1963 (Kyushu).

N essiodocus Zatefasciatus: Anonym, Icon. Ins. Jap. col. nat. ed., II, addenda et corrigenda: $17,1978$.

Specimens examined: Mt. Aoshiodake, Is. Shimo-Koshiki, 1 우, 20. vi. 1970, H. Irie leg. Anbō, Is. Yaku, 1 ㅇ, 19. vii. 1971, H. Irie leg. Shiratani, Is. Yaku, 1 ð 1 우, 11 \& 13. vii. 1973, H. Irie leg.

Distribution: Japan (Honshu, Kyushu, Is. Shimo-Koshiki, Is. Yaku), Taiwan.

Nessiodocus antennalis sp. nov. (Fig. 7, G-I; Photo. P)

Male. Dark reddish brown with brownish and greyish pubescence; head and rostrum covered with greyish pubescence, a little denser around eyes, vertex with a pair of triangular brown patches; pronotum with broad lateral and narrow median stripes in entire length and a transverse median band connecting stripes grey ; scutellum densely covered with grey pubescence ; elytra with following grey patches: antemedian band between 6th intervals extending anteriorly to the base on 1st interval and extending laterally along basal margin as far as 4 th intervals, more or less produced posteriorly on 3rd intervals, postmedian band between 7th intervals shortly and triangularly 
produced anteriorly on 3rd intervals, subapical band extends to lateral margins and produced anteriorly on 5th intervals and both anteriorly and posteriorly on 1 st intervals, 3rd interval with a short basal patch from the basal band, two small patches above and below humeral callus, and short oblique band from the middle of lateral margin to the middle of 7 th interval often extending posteriorly along lateral margin. Legs, pygidium and undersurface greyish.

Head with frons 1/4.4-4.6 the maximum width of rostrum; the latter short, transverse, transversely depressed a little behing anterior margin, lateral carina obsolete. Antennae with $3 \mathrm{rd}$ and 4 th segments slender, 5th to 8th almost as thick as club, with proportions in length from base $10: 6: 14$ : $16: 19: 19: 19: 16: 9: 6: 8$, width of 1 st 6 , 2nd 4.5 , 3rd 4 , 8th 5 , 9th $5.5(30=$ $1 \mathrm{~mm})$.

Pronotum transverse $(9: 5)$, widest at the lateral angles of carina, and straightly narrowing anteriorly, transverse carina bisinuate, obtusely angulate posteriorly at middle, lateral carina straight and reaching third from anterior margin, carinulae distinct.

Elytra parallel-sided, shallowly depressed transversely behind basal margin, subbasal humps very weak, apical margin above pygidium truncate.

Pygidium slightly broader than long, broadly rounded at apex. Tibiae without hump at apex. Venter with 5 th ventrite a little longer than 4 th and weakly produced ventrally.

Female. Unknown.

Length : 4.4-4.6 mm (excl. head).

Holotype đ̋ (Type No. 2195, Kyushu Univ.), Mt. Inunaki, Fukuoka Pref., 21. vii. 1960, J. Nagao leg.

Paratype: Cape Sata, Kagoshima Pref. 1 ð, 31. v. 1959, K. Orita leg.

Distribution: Japan (Kyushu).

Nessiodocus propinquus Shibata (Fig. 7, J-N; Photo. Q, R)

Nessiodocus propinquus Shibata, Ent. Rev. Japan, XXXIV: 24, pl. 2, figs. 4-5, 1980 (Taiwan ; female).

Male. Dark reddish brown with brownish and greyish pubescence; head around eyes, frons and rostrum covered with greyish pubescence, vertex triangularly brownish; pronotum with five greyish stripes, lateral two stripes connate to each other at anterior and posterior margins, median stripe lozengeshaped, median transverse band narrow, connecting median and latero-median stripes ; scutellum greyish; elytra with the similar pattern of markings as antennalis, but the antemedian band continuous laterally to short stripes above and below humeral callus and to lateromedian stripes, antemedian band produced posteriorly on 3rd intervals and connate to postmedian band enclosing median brown spot, 1st intervals behind postmedian band greyish, subapical band often separated into three spots. Legs, pygidium and undersurface greyish. 

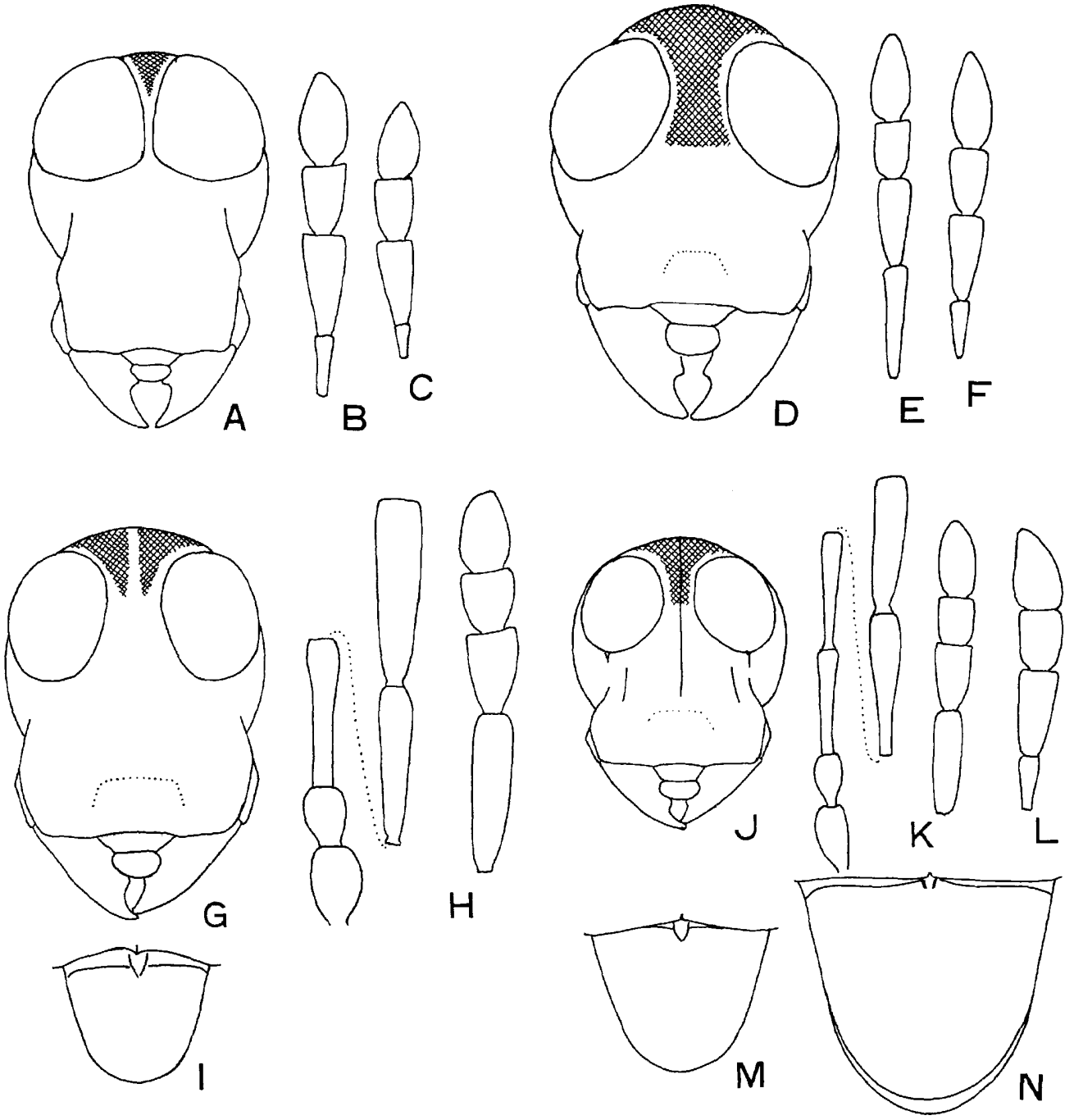

Fig. 7. Nessiodocus spp. A-C: triodes. (A: Male head. B: Antennal club, male. C: Ditto, female). D-F: repandus (D: Female head. E: Antennal club, male. F : Ditto, female). G-I: antennalis sp. nov., male (G: Head. H: Antenna. I : Pygidium). J-N: propinquus. (J: Male head. K: Male antenna. L: Ditto, female. M: Male pygidium. N: Ditto, female).

Head with frons $1 / 5$ times as wide as maximum width of rostrum; rostrum transverse, with a weak median carina extending from the posterior margin of weak transverse depression to vertex and with a pair of short carinae below eyes. Antennae with 2nd and 3rd segments slender, 4th thickened apically, 5 th to 8 th thick, with proportions in length from base $9: 6: 12: 14: 15:$ $16: 16: 12: 8: 6: 8$, width of 1 st 4.5 , 2nd 3.5 , 3rd $2.7,8$ th $3.6,9$ th $4.2 \quad(40=1$ $\mathrm{mm})$. 
Pronotum similar to antennalis, transverse carina weakly and triangularly produced backwards at middle.

Elytra similar to antennalis. Pygidium as long as wide, broadly rounded apically. Tibiae and venter as in antennalis.

Female, Antennae shorter, reaching to the basal third of elytra, 3rd to 8 th segments slender, much narrower than club, with proportions in length from base $8: 6: 11: 11: 10: 9: 9: 8: 11: 7.5: 11$, width of 1 st 5 , 2nd 4.5 , 3rd 2.8 , 8th 3, 9th 5. Pronotal transverse carina not angulate at middle. Pygidium with apical margin double bordered.

Length : 3.1-4.3 $\mathrm{mm}$ (excl. rostrum).

Specimens EXAmined : Mt. Yonahadake, Is. Okinawa, 10, 20. v. 1978, H. Makihara leg. Taminato, Is. Okinawa, 1 , Is. Okinawa, 23. iv. 1973, H. Irie leg. Mt. Omoto, Is. Ishigaki, $1 \precsim$, 21. iv. 1975, H. Irie leg. Mt. Urabuyama, Is. Yonaguni, 1 우, 22. vi. 1972 , H. Irie leg.

Distribution : Japan (Is. Okinawa, Is. Ishigaki, Is. Yonaguni), Taiwan (Mt. Yangmingshan, Liukyei) .

Key to Japanese species of the genus Nessiodocus Heller

1 : Eyes contiguous ; frons linear ; rostrum as long as wide ; antennae with 3rd to 8 th segments slender, 8 th much shorter than 9 th; venter with 5 th ventrite as long as 2nd to 4th taken together measured at middle in male and as long as 3rd and 4th taken together in female; pygidium simply rounded in female ................................................. Nessiodocus triodes Jordan

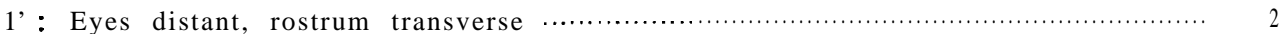

2 : Elytra with narrow antemedian and postmedian bands; pronotum with a narrow median stripe and without transverse median band; antennae with 8 th segment shorter than 9 th and 10 th taken together and much narrower in male; rostrum and head around eyes greyish, but the greyish area not ascending upwards to frons ….................................. Nessiodocus repandus Jordan

2': Pronotum with a transverse median band connecting lateral stripes; elytra with broader bands; greyish area of head ascending upwards from rostrum at least to the middle of frons; antennae in male thicker, 2nd and 3rd segment slender, 4th to 8 th segments thick and scarcely narrower than club, 8th segment at least as long as 9th and 10th taken together

3 : Pronotum with a pair of broad lateral and a narrow median stripes; rostrum without carinae in male; subapical band of elytra w-shaped

Nessiodocus antenna!is sp. nov.

3' : Pronotum with two pairs of lateral and a median stripes; rostrum with carinae in both sexes; subapical band of elytra often separated into three spots

Nessiodocus propinquus Shibata

\section{Cedus Pascoe}

Cedus Pascoe, Ann. Mag. Nat. Hist., (3) V: 37, 1860. (Type-species: Cedus tuberculatus Pascoe, new designation).

Cedus japonicus Shibata (Fig. 8, A, B; Photo. L)

Cedus japonicus Shibata, Ent. Rev. Japan, XV: 43, pl. 6, fig. 1-3, 1963 (Is. Amami), 
Specimen examined: Kenting-park, Pingtun Hs., Taiwan, $1 \precsim$, 3. v. 1971, K. Sasaji leg.

Distribution: Japan (Is. Amami-Oshima), Taiwan-new record.

Note. This species is very close to diversus Jordan (1911) from South India, Tonkin and Taiwan. Shibata (1963) distinguished it from the latter by the characters as "japonicus differs in the shorter elytra which are only onethird longer than the basal width, while nearly twice lengths of the width in diversus, and the base of rostrum with white spots in both sexes, lacking white pubescence in female of the latter". C. diversus was originally described by Jordan (1911) as "Black, in male the base of rostrum and the cheeks, in female only the cheeks creamy white... Elytra nearly twice as long as broad...". The type (Madura, S. India) has much shorter elytra with proportion of length to width as 42 to 27, about the same dimention of japonicus so far I have examined at the British Museum (Natural History), I have only a male of $j a$ ponicus and unable to decide whether they are the same or not.

Cedus insignis Shibata (Photo. K)

Cedus insignis Shibata, Ent. Rev. Japan, XXXIV: 41, fig. 4, 1980 (Chichijima ; male).

Specimens examined: Okimura, Is. Hahajima, $2 \precsim, 5$. vi. 1976, T. Seino leg. Distribution: Japan (Ogasawara Isls.: Is. Chichijima and Is. Hahajima).

\section{Androceras Jordan}

Androceras Jordan, Novit. Zool., XXXIV : 83, 1928 (Type-species : Mucronianus khasianus Jordan, by original designation).

Androceras flavellicornis (Sharp) (Photo. U)

Tropideres flavellicornis Sharp, Trans. Ent. Soc. London, 1891 : 305, 1891 (Junsai) ; Uno, Ent. Rev. Japan, V: 51, pl. 2, fig. 3, 1950 (Hokkaido, Honshu, Kyushu ; redescription) ; Nakane, Icon. Ins. Jap.: 1256, fig. 3618, 1950 (Hokkaido, Honshu, Kyushu) ; Nakane, Icon. Ins. Jap. col. nat. ed., II : 352, pl. 176, fig. 16, 1963 (Hokkaido, Honshu).

Androceras flavellicornis: Shibata, Ent. Rev. Japan, XXII: 22, 1963 (Nara, Wakayama, Osaka, Kyoto, Shiga, Gifu, Fukui, Ishikawa, Miyagi ; redescription).

Specimens examined: 33 exs. from Aomori, Fukushima, Niigata, Ishikawa, Shizuoka, Fukuoka and Kagoshima Prefs.

Distribution: Japan (Hokkaido, Honshu, Kyushu).

\section{Mucronianus Jordan}

Mucronianus Jordan, Novit. Zool., I: 627, 1891; Jordan, Novit. Zool., XXXIV: 83, 1928 (Type-species : Mucronianus rufipes Jordan, by original designation).

Mucronianus takemurai (Nakane) (Fig. 8, C-E; Photo. S, T)

Litocerus takemurai Nakane, Fragm. Col., (8): 32, 1963 (Mt. Kirishima; male) ; Nakane, Icon. Ins. Jap. col. nat. ed., II: 351, pl. 176, fig. 4, 1963 (Kyushu).

Mucronianus takemurai: Shibata, Ent. Rev. Japan, XXII: 20, pl. 4, fig. 1, 1969 (Is. Yaku; redescription). 


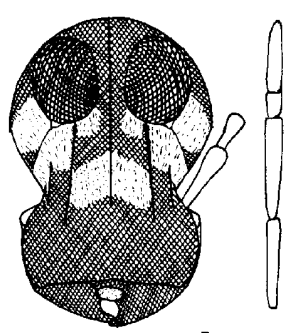

A
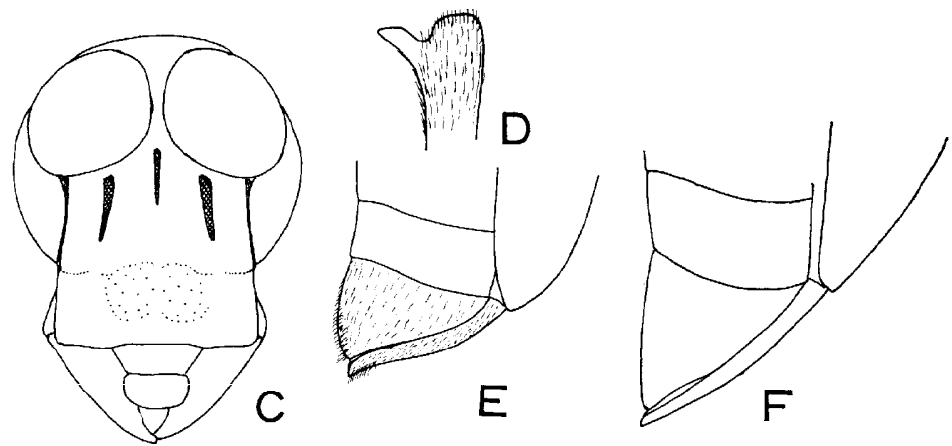

Fig. 8. A, B: Cedus japonicus, head and antennal club. C-F : Mucronianus takemurai (C: Male head. D: Apex of male front tibia. E: Male pygidium, lateral aspect. F. Ditto, female).

Specimens examined: Miyanoura, Is. Yaku, 18, 15. vii. 1971, J. Komiya leg. Tsubokiriyama, Is. Yaku, 1 우, 24. vii. 1970, H. Irie leg.

Distribution : Japan (Kagoshima, Is. Yaku).

Note. This genus was characterized by Jordan (1928) as "Basal margin of elytra straight; male pygidium produced into a conical projection". His definition comes from rufipes as illustrated by me (1972), but the other species now listed in Coleopterorum Catalogus and its Supplementa do not agree with this definition in several points. The basal margins of elytra are weakly produced anteriorly in rufipes philippinensis Heller, virgatus Jordan and takemurai Nakane, and more produced as in Nessiodocus in the others. The male pygidium is conically pointed only in rufipes. The rostrum is carinate in rufipes, virgatus and takemurai.

Mucronianus axius and tenuicornis are seemed to be members of Nessiodocus, and repandus was already transferred to Nessiodocus. $M$. takemurai is close to virgatus Jordan from Laos, but the greyish stripes are widely interrupted at middle.

\section{Acorynus Schoenherr}

Acorynus Schoenherr, Gen. Sp. Curc., I: 123, 1833 (Type-species: Anthribus sulcirostris Dom. = Acorynus sulcirostris Boheman).

Acorynus asanoi (Nakane) (Fig. 10, A; Photo. Y)

Tropideres asanoi Nakane, Fragm. Col., (8) : 33, fig. 3, 1963 (Is. Yaku, Sata).

Acorynus asanoi: Nakane, Kitakyushu no Kontyu, 24: 80, fig. 4, 1978.

A corynus anchis Shibata (nec Jordan), Ent. Rev. Japan, XVI: 5, pl. 1, fig. 6, 1963 (Is. Amami, Is. Yaku, Kagoshima)

Acorynus asanoi mikuraensis Nakane, Kitakyushu no Kontyu, 24: 8, fig. 3, 1978.-Syn. nov.

Specimens examined : 27 exs. from Is. Amami-Oshima, Is. Yaku, Is. Kuroshima, Kagoshima Pref. :Sata, and Is. Mikura).

Distribution: Japan (Kagoshima, Is. Yaku, Is. Amami-Oshima, Is. Mikura).

Note. The subspecies mikuraensis was described on a female as; 
asanoi asanoi: Elytra with basal and apical greyish patches completely divided by broad blackish median band even at suture.

asanoi mikuraensis: Basal and apical greyish patches narrowly connate along suture.

So far as I have examined, many specimens from Is. Mikura have the complete transverse black band just the same as specimens from Is. AmamiOshima and Is. Yaku, and impossible to separate them as different subspecies.

Acorynus poecilus Shibata (Fig. 9, F ; 10, D; Photo. X)

Acorynus poecilus Shibata, Ent. Rev. Japan, XVI: 4, pl. 1, fig. 5, 1963 (Is. Ishigaki ; female)

Specimens examined: Mt. Banna, Is. Ishigaki, 1 우, 3. v. 1969, H. Makihara leg. Yoshihara, Is. Ishigaki, $2 \rtimes 2$ 우, 2. iv. 1973, H. Irie leg. ; 6 § 1 우, 27. iv. 1974, H. Irie leg. Mt. Omotodake, Is. Ishigaki, 1우, 7. vi. 1962, H. Irie leg. ; 6 Ђ

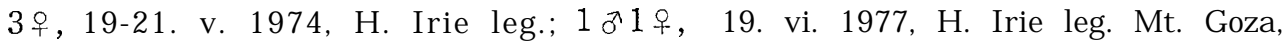
Is. Iriomote, 1 ð, 15-21. iv. 1969, H. Makihara leg. Mokutan, Is. Iriomote, 1 우, 23. vi. 1970, H. Makihara leg. Shirahama, Is. Iriomote, 2 ð 1 우, 3. v. 1974, H. Irie leg. Arakawa, Is. Ishigaki, $1 \succsim$, 19. v. 1974, H. Irie leg.

Distribution: Japan (Is. Ishigaki and Iriomote).

Note. As properly pointed out by Nakane (1978), this species is close to anchis Jordan from Taiwan, but the brownish grey basal and postmedian patches are always connate on 1 st and 2nd intervals and postmedian whitish patches are connate internally to it, pronotum has wider greyish patches, and the dorsal plate of pennis is as wide as ventral one, while in anchis the brownish grey basal and postmedian patches are divided at middle, the postmedian patches are enclosed by black area, and the dorsal plate of pennis is distinctly wider than the ventral one.

Acorynus singularis Shibata

Acorynus singularis Shibata, Ent. Rev. Japan, XVI : 6, pl. 1, fig. 8, 1963 (Is. Amami; female).

Distribution: Japan (Is. Amami-Oshima).

This species remains unknown to me.

Acorynus latirostris (Sharp) (Fig. 9, D; 10, B 11, H; Photo. V)

Tropideres latirostris Sharp, Trans. Ent. Soc. London, 1891: 303, 1891 (Nikko, Kiga, Higo, Oyayama, Kurigahara); Uno, Ent. Rev. Japan, V: 49, pl. 2, fig. 1, 1950 (Honshu, Kyushu; redescription) ; Nakane, Icon. Ins. Jap.: 1256, fig. 3616, 1950 (Honshu, Kyushu) ; Nakane, Icon. Ins. Jap. col. nat. ed., II: 352, pl. 176, fig. 7, 1963 (Honshu, Shikoku, Kyushu).

Acorynus latirostris: Shibata, Ent. Rev. Japan, XVI: 6, pl. 1, fig. 7, 1963 (Honshu, Shikoku, Kyushu, Tsushima ; redescription) ; Nakane, Kitakyushu no Kontyu, 24: 80, fig. 1, 1978.

Specimens examined : 34 exs. from Aomori, Fukushima, Gunma, Kōchi, Fukuoka, Kumamoto, Miyazaki and Kagoshima Prefs., and Tsushima.

Distribution: Japan (Honshu, Shikoku, Kyushu, Tsushima). 
Acorynus okinawanus sp. nov. (Fig. 9, A, B ; 10, C; 11, G; Photo. W)

Male. Dark brown, with blackish patches on pronotum and elytra; with luteous grey pubescence; head with triangular blackish patch on vertex, eyes with greyish fringe; pronotum with five striae, the median and latero-median stripes interrupted at middle, lateral stripes interrupted before middle, with a pair of small patches at middle; elytra with the basal large patch completely encloses black spot on the 2nd to 4th intervals, humeral callus blackish, median transverse patch lying between 2nd and 5th intervals narrow, often produced anteriorly on 3rd and 5th intervals, posterior large patch mingled with small black spots near apex. Undersurface with greyish pubescence. Femora except for the blackish patch on hind one with greyish pubescence. Tibiae with antebasal and postmedian greyish rings and with greyish lower margin. Tarsi with 1st segment greyish at apex. Pygidium with luteous grey pubescence, darker median stripe indistinct.

Head with frons narrowly distant; rostrum slightly wider than long, with five carinae, median carina extending from anterior margin to the narrowest portion of frons, latero-median carinae not reaching eyes and ending at the middle of rostrum. Antennae with proportions in length from base $9: 10: 13$ : $13: 11: 9: 8: 6: 20: 6.5: 23$, width of 10 th $6(40=1 \mathrm{~mm})$.

Pronotum transverse $(7: 5)$, disk with small, distinct punctures, transverse median depression shallow and indistinct, transverse carina slightly arched posteriorly at middle, carinulae absent

Elytra similar to anchis, poecilus and latirostris,3rd, 5th and 7th intervals slightly convex, basal margin weakly arched anteriorly and finely marginate.

Pygidium rather broadly rounded at tip. Venter flattened at middle, weakly concave in profile.

Female. Pygidium evenly rounded at apex. Venter flat in profile.

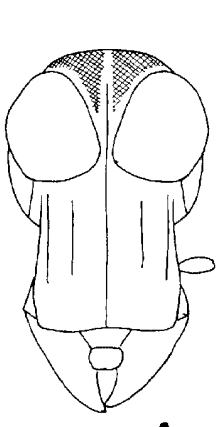

A

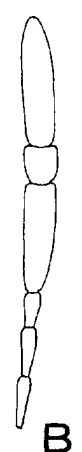

B
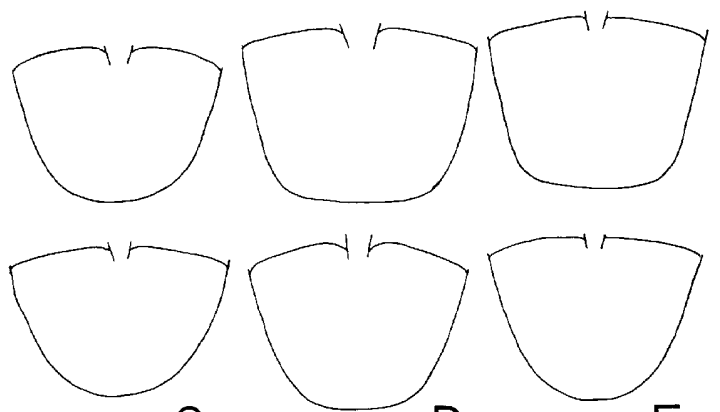

C

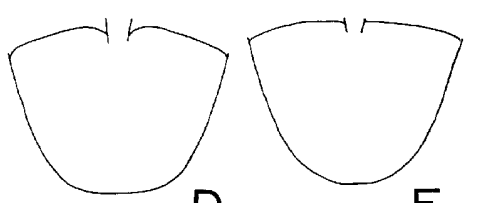

E

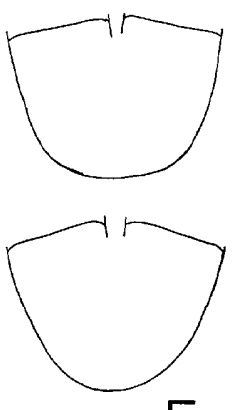

$\mathrm{F}$

Fig. 9. Acorynus spp. A, B: okinawanus sp. nov., male head and antenna. C-F : Pygidium, top male, bottom female (C: okinawanus. D: Zatirostris. E: anchis. F: poecilus). 

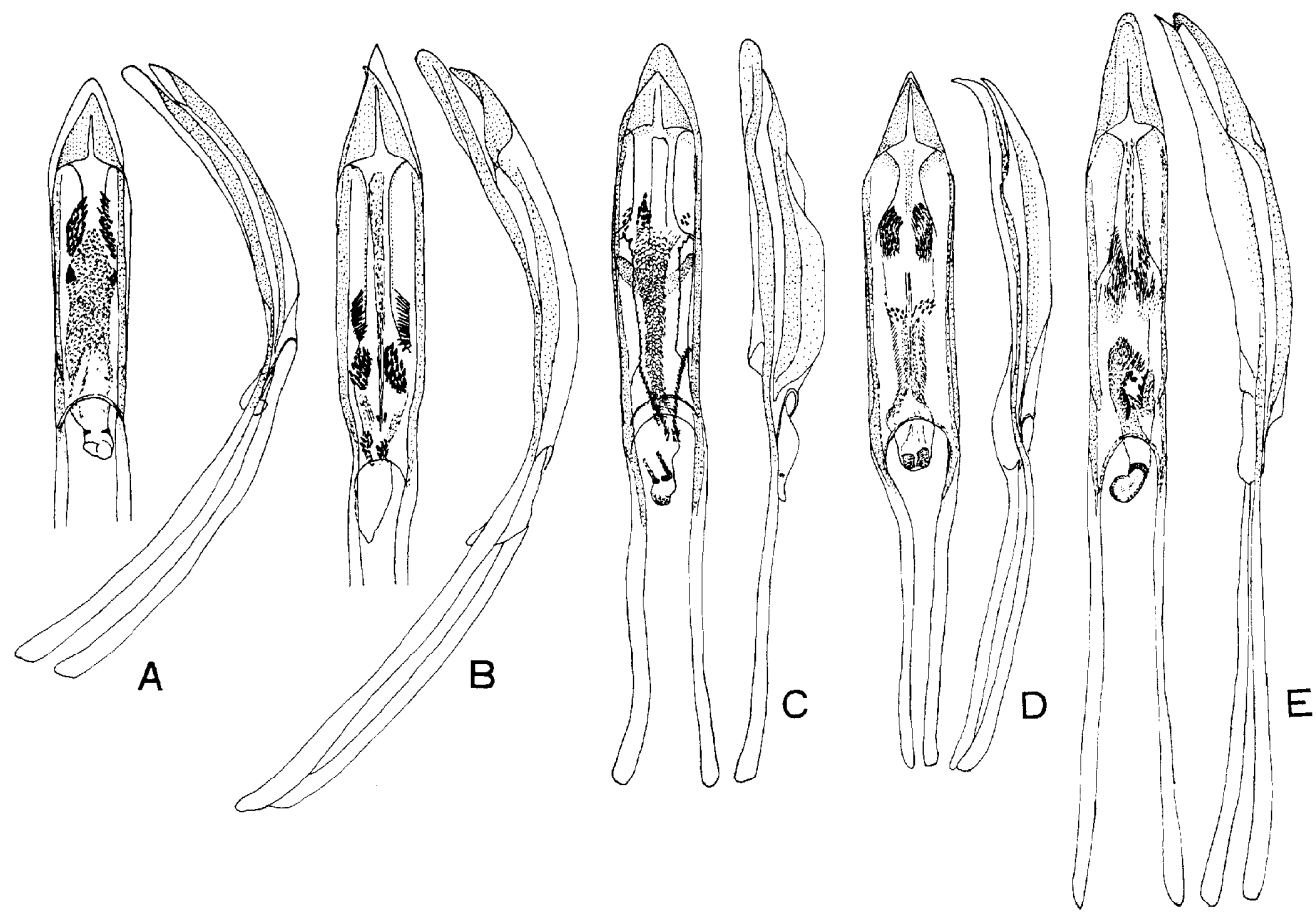

Fig. 10. Acorynus spp., penis, dorsal and lateral aspects (A: asanoi. B: latirostris. C: okinawanus. D: poecilus. E: anchis).

Length : 5.2-5.9 mm (excl. head).

Holotype § (Type No. 2196, Kyushu Univ.), Yona, Is. Okinawa, 2. iv. 1975.

H. Irie leg.

Paratypes: Same locality as type, 1 ㅇ, 24. iii. 1964, T. Shirōzu leg. ; 2 ð, 12 17. vi. 1970, H. Makihara leg. 2 우, Mt. Yonahadake, Is. Okinawa, 21 \& 22. v. 1976, T. Ogasawara leg.; 1 우, 27. vi. 1977, J. Irie leg.

Distribution: Japan (Is. Okinawa).

$$
\text { K ey to species of the Genus Acorynus from J A P N }
$$

1 : A pair of spots in the broad transverse black band on elytra vestigial or ab-

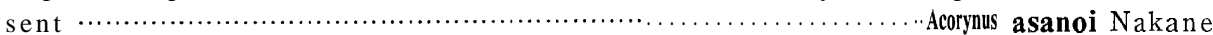

$1^{\prime}$ : A pair of spots in the blackish transverse band on elytra always distinct $\cdots \cdots \cdots \cdot \ldots$

2 : Eyes completely fringed with greyish or luteous grey pubescence ; tibiae with antebasal and postmedian greyish rings

2': Greyish fringe around eyes interrupted above eyes ; tibiae usually with a postmedian broad greyish ring, basal ring indistinct if present; a pair of spots in the broad transverse black band on elytra same colour as basal and apical patches

3 : Sutural intervals with luteous grey pubescence in entire length, not interrupted, a pair of spots in the blackish band white. .................Acorynus poecilus Shibata

3': Sutural intervals with a black spot separating basal and apical patches at mid- 


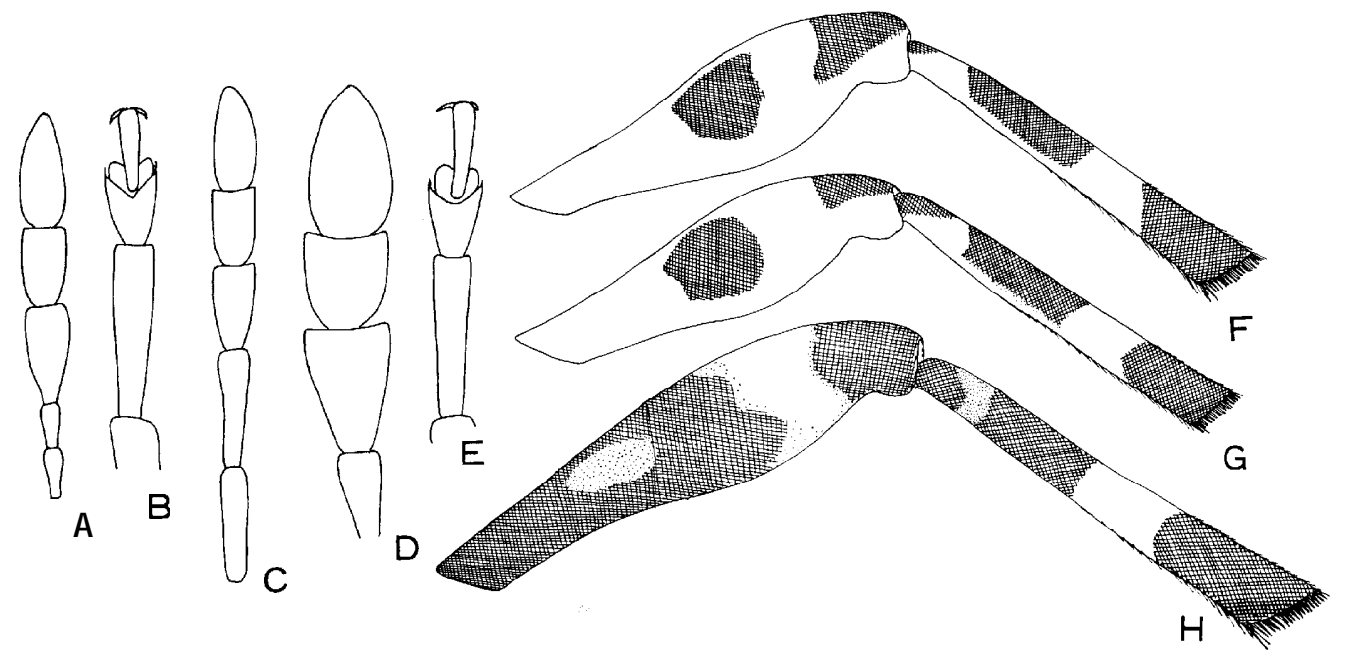

Fig. 11. Litocerus spp. A, B: laxus, female antenna and right front tarsus. C: kimurai, male antenna. D, E: securus (D: Male antenna. E: Right front tarsus). F-H. Acorynus spp., hind leg. (F :anchis. G: okinawanus. H: latirostris).

dle, or blackish band completely divided the patches and encloses a pair of spots

4 : Pygidium subquadrate in male, a pair of spots in the broad blackish band subdivided into small spots on 2 nd and 3 rd to 6 th intervals, often they are whitish (Taiwan) -Acorynus anchis Jordan

4' : Pygidium broadly rounded at tip in male, a pair of spots in the broad blackish band same colour as basal and apical patches, not separated, more or less produced anteriorly on $3 \mathrm{rd}$ and 5 th intervals ..............Acorynus okinawanus sp. nov.

\section{Litocerus Schoenherr}

Litocerus Schoenherr, Gen. Sp. Curc., I: 125, 1833. (Type-species: Litocerus histrio Gyllenhal, by original designation)

Tropideres and Litocerus are very close to each other in many characters, and paviei Lesne, laxus Sharp and securus Boheman are regarded as the intermediate of both genera. In this paper I will define them as follows:

Tropideres: Antennae with club compactly articulated, penultimate segment broader than long and much shorter than 9th; tarsi with 1st segment shorter than the remainings taken together.

Litocerus : Antennae with club loosely articulated, penultimate segment longer than wide, as long as or slightly shorter than 9th ; tarsi with 1st segment longer than the remaining segments taken together.

Litocerus communis communis Jordan (Photo. Z)

Litocerus communis Jordan, Novit. Zool., XIX: 139, 1912 (Formosa: Taihorisho Fuhosho, Hoozan, Kosempo and Alikong).

Specimens Examined: Ushikumori, Is. Iriomote, $1 \precsim$, 7. viii. 1962, M. Sato \& Y. Arita leg. Kampire fall, Is. Iriomote, $1 \delta^{\Uparrow 1} 1$ ㅇ, 7. iv. 1973, H. Irie leg. 
Nakara Riv., Is. Iriomote, $1 \succsim$, 25. vi. 1970, H. Makihara leg. Shirahama, Is. Iriomote, 1 우, 31. viii-5. ix. 1969, H. Makihara leg. Yoshihara, Is. Ishigaki, 2 ㄲ 4 우, 2. iv. 1973, H. Irie leg.; 1 우, 25. v. 1974, H. Irie leg. ; 2 乃1우, 17. vi. 1977, H. Irie leg. Nanshanchi, Nantou Hs., Taiwan, 1 ㅇ, 30. vi. 1965, Y. Kurosawa leg.; 2 우, 9. vii. 1966, H. Sasaji leg. ; 1 ð 2 우, 16. v. 1971, K. Sakai leg. Lushan Wenchuan, Nanton Hs., Taiwan, 2 ๘, 6-7. vi. 1976, H. Makihara leg. Liyuchih, Haulien Hs., Taiwan, $1 \curvearrowright$, 14. vii. 1966, H. Sasaji leg. Kukan, Taichun Hs., Taiwan, 1 § 1 ㅇ, 1 \& 10. vi. 1976, H. Makihara leg. Lushan, Nantou Hs., Taiwan, 1 ㅇ , 20. vi. 1976, H. Makihara leg.

Distribution : Japan (Is. Ishigaki and Iriomote), Taiwan.

Litocerus communis amamianus Shibata (Photo. a)

Litocerus communis amamianus Shibata, Ent. Rev. Japan, XXII: 16, pl. 3, fig. 1 \& 2, 1969 (Is. Amami).

Specimens examined: Mt. Yuwan, Is. Amami-Oshima, 2 우, 6. viii. 1963, T. Okada leg.;1ㅇ, 16. vii. 1963, C. M. Yoshimoto leg. ; 1 ð 1 ㅇ, 17. vii. 1963, T. Yamazaki leg.; 4 ○ 2 우, 29-30. vii. 1963, Y. Hirashima \& J. L. Gressitt leg. Hatsuno, Is. Amami-Oshima, $1 \precsim$, 31. iii. 1968, H. Makihara leg. Shinmura, Is.

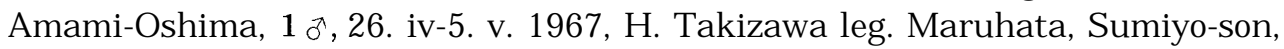
Is. Amami-Oshima, $1 \delta^{\circledR} 1$ ㅇ, 8. iv. 1977, T. Ogasawara leg. Yona, Is. Okinawa, 1 오, 22. iv. 1962, H, Makihara leg.;1 ㅇ, 15. vi. 1970, H. Makihara leg. Oku, Is. Okinawa, 1 § 5 우, 15-18. v. 1978, H. Makihara leg. Mt. Yonahadake, Is. Okinawa, 1 우, 17. iv. 1974, H. Irie leg.

DistRibution: Japan (Is. Amami-Oshima and Okinawa).

\section{Litocerus tokarensis tokarensis (Nakane) (Photo. b)}

Tropideres tokarensis Nakane, Fragm. Col., (8) : 33, 1963 (Is. Nakanoshima) ; Nakane, Icon. Ins. Jap. col. nat. ed., II: 352, pl. 176, fig. 18, 1963 (Is. Nakanoshima, Is. Amami-Oshima)

Litocerus tokarensis: Shibata, Ent. Rev. Japan, XXII: 17, pl. 3, fig. 3-5, 1969 (Is. Amami, Is. Yaku) ; Anonym, Icon Ins. Jap. col. nat. ed., II, addenda et corrigenda: 17, 1978.

Specimens EXAmined : Is. Nakanoshima, Tokaras, 1 ๙ , 26. vi. 1973, $\mathrm{H}$. Makihara leg. ; $1 \succsim 1$ 우, 2. vii. 1973, H. Irie leg. Yuwan, Is. Amami-Oshima, 1 우, 30. vi. 1963, H. Hirashima leg.

Distribution: Japan (Is. Nakanoshima and Amami-Oshima).

Litocerus tokarensis insensibilis Shibata (Photo. c)

Litocerus tokarensis f. insensibilis Shibata, Ent. Rev. Japan, XXII: 18, pl. 3, fig. 5, 1969 (Is. Yaku).

Litocerus tokarensis insensibilis Shibata, Ent. Rev. Japan, XXXIV: 40, fig. 2, 1980 (Is. Yaku, Mt. Ichifusa).

Specimen eXamined: Mt. Takatsuka, Is. Yaku, 1 ð̊, 21. vii. 1974, H. Irie leg. DisTRIBUTION : Japan (Is. Yaku). 
Litocerus tokarensis ogasawaranus Shibata

Litocerus tokarensis ogasawaranus Shibata, Ent. Rev. Japan, XXXIV: 41, fig. 3, 1980 (Chichijima ; female).

Distribution: Japan (Ogasawara Isls.: Chichijima).

Litocerus multiguttatus (Nakane) (Photo. e, f)

Tropideres multiguttatus Nakane, Fragm. Col., (8) : 33, fig. 2, 1963 (Mie, Hida, Kamikochi, Kyoto, Fukuoka) ; Nakane, Icon. Ins. Jap. col. nat. ed., II: 351, pl. 176, fig. 12, 1963 (Honshu).

Litocerus bicuspis multiguttatus: Shibata, Ent. Rev. Japan, XXII: 18, pl. 3, fig. 6 \& 7, 1969 (Kagoshima, Kochi, Kyoto, Nagano, Kanagawa).

Litocerus multiguttatus: Anonym, Icon. Ins. Jap. col. nat. ed., II, addenda et corrigenda: 17, 1978.

Specimens examined: Fuji-rindb, Yamanashi Pref., 1우 26. vi. 1977, T. Ogasawara leg. Mt. Fukuchi, Fukuoka Pref., $1 \overbrace{}^{\star}$, 27. vii. 1970, H. Makihara leg. Mt. Inunaki, Fukuoka Pref., 1 ㅇ , 3. viii. 1960, J. Nagao leg. Mt. Kirishima, 2 우, 17. vii. 1933, Hori \& Fujino leg.; 1 우, 1. viii. 1959, H. Maebara leg. ;1우, 22. vii. 1956, J. Nagao leg. ; 1 ð 1 ㅇ, 5. viii. 1970, K. Morimoto leg. Takatsukayama, Is. Yaku, 1 ๙ , 19. vii. 1974, H. Irie leg.

Distribution: Japan (Honshu, Kyushu, Is. Yaku).

Note. The two brushes of yellow hairs on the first and second ventrites in male are very distinctive characteristic of the present species and bicuspis Jordan, and Shibata (1969) treated this as a subspecies of the latter on this point. But bicuspis is different in having broad lateral stripes on pronotum, subquadrate distinct basal patches on 2nd-4th intervals and broader postmedian patches on 2nd-6th intervals, and 9th-11th segments of antennae of subequal in length.

Litocerus kimurai Shibata (Fig. 11, C: Photo. d)

Litocerus kimurai Shibata, Ent. Rev. Japan, XXII: 19, pl. 3, fig. 8 \& 9, 1969 (Mt. Hiko, Mie, Tsushima).

Specimens examined: Mt. Hiko, Fukuoka Pref., 1 ㅇ, 21. vii. 1970, S. Ogata leg. Kusukawa, Is. Yaku, 1 ㅇ, 17. vii. 1971, H. Irie leg. Kosugidani, Is. Yaku, 1 §, 2-4. vi. 1969, H. Makihara leg.

Distribution: Japan (Honshu, Kyushu, Tsushima, Is. Yaku).

Litocerus laxus (Sharp), comb. nov. (Fig. 11, A, B; Photo. h)

Tropideres laxus Sharp, Trans. Ent. Soc. London, 1891: 304, 1891 (from Yezo to Yuyama) ; Yuasa, Icon. Ins. Jap. : 547, fig. 1069, 1932; Kato, Three col. ill. ins. Jap. IX: pl. 26, fig. 5, 1933; Kamiya and Adachi, Col. ill. Col. Jap., pl. 46, fig. 16, 1933 ; Esaki, Hori \& Yasumatsu, Ins. Jap. ill. icon. col. nat. dep.: 311, pl. 141, f. 350, 1939; Hirayama, Nat. col. ill. Col.: 78, pl. 28, fig. 31, 1934; Nakane, Icon. Ins. Jap. : 1256, fig. 3620, $1950 ; \mathrm{Na-}$ kane, Icon. Ins. Jap. col. nat. ed., II: 352, pl. 176, fig. 15, 1963.

Specimens examined : 103 exs. from Hokkaido (Sapporo), Aomori, Fukushima, Gunma, Tokyo, Shizuoka, Fukui, Saitama, Okayama, Kōchi, Ehime, 
Fukuoka, Kumamoto, Ōita, Miyazaki, Kagoshima and Tsushima).

Distribution : Japan (Hokkaido, Honshu, Shikoku, Kyushu, Tsushima), China (Fukien).

Note. This common species has been recorded or illustrated correctly by many entomologists under Tropideres. The antenna1 clubs of laxus and paviei are much wider than funicle, and the latter species has often been treated under Litocerus or Tropideres because of their intermediate shape of antenna 1 clubs. I treat both species in Litocerus according to the definitions of these genera noted above in this paper.

Litocerus securus (Boheman), comb. nov. (Fig. 11, D, E; Photo. g)

Tropideres securus Boheman, Gen. Spc. Curc. V: 207, 1939 (Calcutta).

Litocerus rufescens Roelofs, Ann. Soc. Ent. Belg., XXII, compt. rend. : 1v, 1879 (Japon) ; Roelofs, Ann. Soc. Ent. Belg., XXIII: 28, 1880.

Tropideres rufescens : Sharp, Trans. Ent. Soc. London, 1891: 307, 1891; Nakane, Icon. Ins. Jap. col. nat. ed., II: 352, pl. 176, fig. 11, 1963 (Honshu, Shikoku, Kyushu) ; Oda, Trans. Shikoku Ent. Soc., 14: 114, fig. 11, 20, 29, 40, 51, 63, 76, 1979 (Honshu, Shikoku, Kyushu,

Is. Yaku, Is. Amami-Oshima).

Litocerus anna Jordan, Novit. Zool., X: 424, 1903 (Kina Balu).

Specimens examined : 58 exs. from Gunma, Tokyo, Is. Hachijo, Kōchi, Fukuoka, Kumamoto, Kagoshima, Is. Yaku, Thailand (Mae Sa Water-fall).

Distribution: Japan (Honshu, Shikoku, Kyushu, Is. Hachijo, Is. Yaku, Is. Amami-Oshima), Taiwan, China, Tonkin, Thailand, India, Borneo, Java.

KEY TO SPECIES OF THE GENUS Litocerus FROM JAPAN*

1 : Rostrum without dorsal carina ; antennal clubs much wider than funicle, 10th segment a little longer than wide; thoracic dorsal carina forming a curve with its convexity forwards and shortly concave posteriorly at middle ; pronotum without distinct transverse median sulcus, median stripe narrowed in front and again before carina and with traces of several lateral spots; elytra with a reverse pyriform common patch behind scutellum, a large triangular common patch behind middle between 5th intervals, short transverse band behind the patch between 3rd intervals on declivity, and a small common patch at apex; these clayish to greyish patched area more or less reddish in ground colour in contrast to black general tint. Length : 3. 2-4. $0 \mathrm{~mm}$ (excl. head) $\cdots \cdots \cdots \ldots \ldots . . . . .$.

Litocerus securus (Boheman)

1': Rostrum with dorsal carinae; pronotum with distinct transverse median sul-

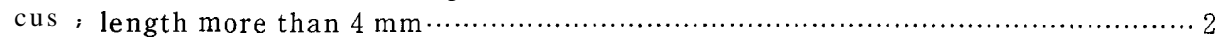

2 : Male antennae with slender club of the same width to 8th segment; elytra with antemedian, postmedian and subapical zig-zag bands greyish to reddish grey leaving blackish humeral callus

2': Male antennae with club much wider than funicle; elytra blackish with small greyish to yellowish grey spots

3 : Tarsi black, without any ring; elytra with black basal spot between scutellar and 3rd striae open anteriorly; pronotum and elytra black with reddish to luteous pubescent patches. Length : 7.8-8.8 $\mathrm{mm}$ (excl. head)

* L. tokarensis ogasawaranus is not included. 
3' : Tarsi with 1st segment whitish on the basal half; elytra with basal band separating the subbasal crescent black spot from the base ; pronotum and elytra black with luteous grey to greyish patches. Length : 4.5-7.8 $\mathrm{mm}$ (excl. head) Litocerus communis Jordan..... 5

4 : Elytra with antemedian and postmedian bands connate on 2 nd striae and enclosing a median black spot on suture; venter with distinct brownish patches ........... Litocerus tokarensis tokarensis (Nakane)

4': Elytra with broad black median band separating anterior and posterior patches; venter with lateral brown patches indistinct

Litocerus tokarensis insensibilis Shibata

5 : Tarsi with greyish pubescence on 2nd segment; elytra with a pair of postmedian patches larger, slightly sinuate anteriorly.

Litocerus communis communis Jordan

5'. Tarsi with 2nd segment black, without grey pubescence; elytra with a pair of postmedian patches narrower and M-shaped

Litocerus communis amamianus Shibata

6: Tibiae with a postmedian greyish ring; tarsi with 1st segment not sharply ringed with greyish pubescence; 1 st and 2 nd ventrites each with a small median yellowish hair tuft in male; pronotum and elytra with many greyish small spots. Length : $5.0-6.4 \mathrm{~mm}$ (excl. head) …......Litocerus multiguttatus (Nakane)

6': Tibiae with two rings; tarsi with terminal whitish ring on 1 st segment; male

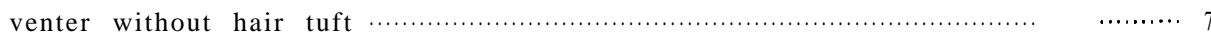

7 : Tibiae with antemedian and postmedian distinct rings; pronotum with three greyish spots behind carina, the median one quadrate; elytra with small patch adjacent to scutellum yellowish grey, with a pair of white bands between exterior margin of 2 nd to 5 th intervals behind middle; rostrum, frons, and cheeks densely clothed with white pubescence. Length : 5.3-7.5 mm (excl.

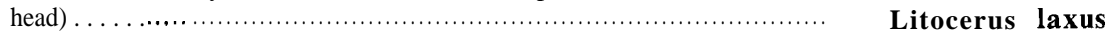

7' : Tibiae with antemedian and terminal rings ; elytra with a star-shaped common patch at base and many small spots yellowish grey to grey, postmedian spots more or less transversely arranged on 2nd to 5th striae. Length : 4.2-6.3 mm (excl. head)

Litocerus kimurai Shibata

\section{Gonotropis LeConte}

Gonotropis LeConte, Proc. Amer. Phil. Soc., XV: 393, 1876 (Type-species: Gonotropis gibbosus LeConte, by monotypy=Tropideres dorsalis Thunberg, after Valentine, 1960)

Gonotropis insignis sp. nov. (Fig. 12, A-C; Photo. i)

Male. Black, densely covered with blackish and whitish to yellowish white pubescence ; rostrum and head between and below eyes clothed with yellowish to whitish pubescence; pronotum with a median and two pairs of small lateral whitish patches, scutellum densely covered with similar pubescence, elytra with a large common post-basal patch between 5th intervals, the patch extending anteriorly to the base between 2nd striae and again expanding laterally as far as 3rd intervals along basal margin, triangularly pointed laterally from 3rd intervals behind subbasal humps, and the patch usually marginate with paler or yellowish pubescence; postmedian patches on 2nd to 4th intervals narrowly connate to each across suture, odd intervals with several 
small spots ; underside excepting prosternum, coxae and femora excepting apical and swollen areas covered with white pubescence; tibiae each with a antebasal ring, tarsi entirely black; pygidium with a median stripe of the similar pubescence, which weakly dilated apically.

Head densely punctate, frons between eyes much narrower than the minimum width of rostrum; eyes latero-dorsal, their external margin visible from above at the same time; rostrum gradually narrowed to the middle, then suddenly widened before antenna1 insertions and weakly widening thenceforwards; anterior margin truncate, with an indistinct emargination at middle ; dorsal surface uneven with a median carina, which extending from a little behind apex to frons and with two pairs of indistinct lateral carinae; antennae reaching about the middle of elytra, each segment clavate, with proportions in length from base $10: 6: 16: 13: 12: 12: 11: 9: 12: 5: 8$, width of 1 st 6 , 3rd 6, 9th $8(30=1 \mathrm{~mm})$.

Pronotum subtrapezoid, $2 / 3$ times as long as wide, dorsal carina angulate toward scutellum at middle and sinuate at sides, lateral carina constricted at middle, carinulae indistinct; disc with a short median glossy impression and transversely depressed across the anterior margin of the impression, distinctly swollen just behind the depression, surface densely punctulate and punctate.

Scutellum small, transverse.

Elytra parallel-sided, with a large elevation near the base of 3rd interval; striae with small punctures, intervals flat except for the 3rd and 5th intervals, which weakly costate behind middle. Pygidium a little wider than long.

Mesosternal process truncate between the middle of median coxae, metasternum and venter finely punctulate. Tarsi with 1st segment a little longer than the 2nd and 3rd taken together, claws sharply dentate.

Female. Antennae shorter, reaching posteriorly a little beyond humeri, with proportions in length $9: 7: 9: 7: 7: 6: 6: 5.5: 11: 6: 10$, width of 1 st 5 , 3rd 3.5, 9th $7.5(40=1 \mathrm{~mm})$.

Length : 3.9-4.9 mm (excl. head).

Holotype o (Type No. 2197, Kyushu Univ.), Jushichinosawa, Mt. Nipesotsu, Hokkaido, 17. vii. 1976, H. Irie leg.

Paratypes: $2 \precsim 1$ 우 , same data as type. $1 \precsim$, Ochiho, Saghalien, 11. viii. 1922, T. Esaki leg.

Distribution: Japan (Hokkaido), Saghalien.

коте. This new species is close to crassicomis Sharp and dorsalis Thunberg, but easily separable from them by the following points: Median cruciferous scaly patch on pronotum narrower, derm unicoloured black; tarsi black without whitish scales, tibiae with an antebasal whitish ring and the rest black; basal patch on elytra shorter and triangularly acuminate laterally, 

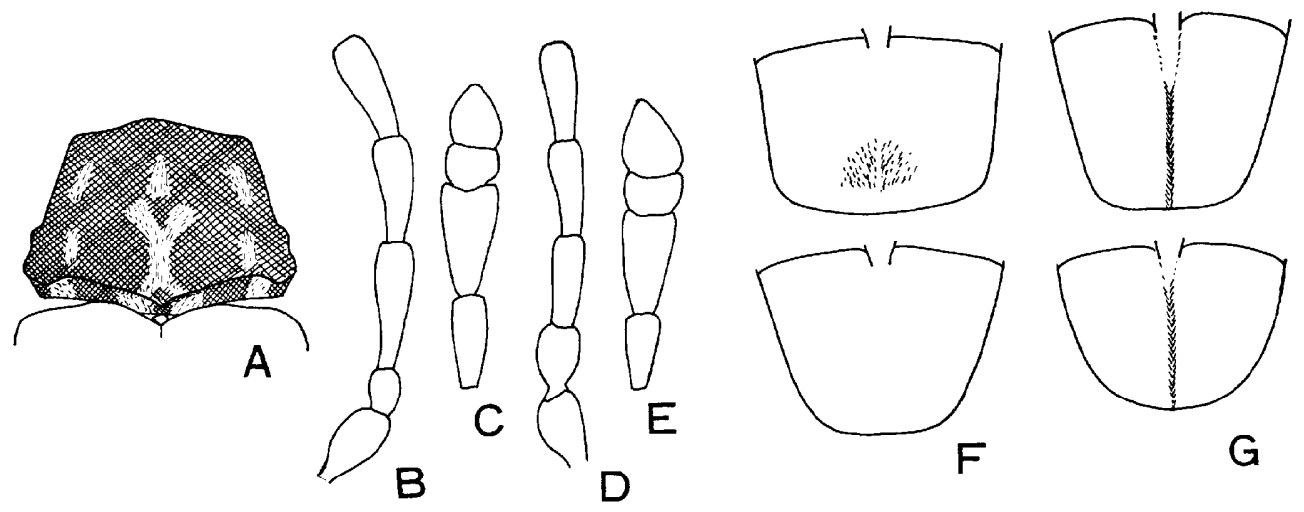

Fig. 12. A-C: Gonotropis insignis sp. nov., male (A: Pronotum. B, C: Antenna). D, E: Gonotropis crassicornis, male antenna. F-G: Pygidium, top male, bottom female (F: Tropideres japonicus japonicus. G: Tropideres japonicus odai ssp. nov.).

tarsal claws sharply dentate. G. dorsalis has simple claws on tarsi according to the description (LeConte, 1876, and Blatchley and Leng, 1916), or "distinctement dentès" (Hoffmann, 1945).

Gonotropis crassicornis (Sharp) (Fig. 12, D, E; Photo. j)

Tropideres crassicornis Sharp, Trans. Ent. Soc. London, 1891: 306, 1891 (Junsai) ; Nakane, Icon. Ins. Jap. col. nat. ed., II: 351, pl. 176, fig. 14, 1963 (Hokkaido, Honshu).

Gonotropis crassicornis : Oda, Trans. Shikoku Ent. Soc., 14: 111, fig. 1, 9, 19, 28, 37, 47, 56, 64, 75, 1979 (Hokkaido, Honshu).

Specimens examined : Toyohara, Ikutahara-cho, Hokkaido, 2 ㅇ, 29. vii. 1976, H. Irie leg. Horoka, Kamishihoro-cho, Hokkaido, 1 우, 31. vii. 1976, H. Irie leg. Hirakubo, Hinoemata-son, Fukushima Prof., 1우.8. viii. 1976, H. Irie leg. Fuji-rindo, Mt. Fuji, Yamanashi Pref., 1 ๙, 10. viii. 1976, H. Irie leg. Shirafune, Nagano Pref., $1 \delta^{\rtimes} 1$ 우 , 17. vii. 1957, J. Nagao leg.

Distribution : Japan (Hokkaido, Honshu).

\section{Gonotropis murakamii Oda}

Gonotropis murakamii Oda, Trans. Shikoku Ent. Soc., 14: 111, fig. 2, 10, 38, 74, 1979 (Kosawa, Uranikko, Tochigi Pref.; female)

Specimens examined: Nikamatasawa, Katashina-son, Gunma Pref., 2 ð 2 우, 16 \& 18. vii. 1975, H. Irie leg.

Distribution: Japan (Honshu: Gunma and Tochigi Pref.).

Note. This species was described on two females. Male has longer antennae, which are reaching a little behind the middle of elytra and the relative lengths of segments from base are $9: 6: 14: 12: 12: 11: 10: 8: 9: 4:$ 8 , width of 1 st 6 , 3rd 6 , 9 th $8(30=1 \mathrm{~mm})$.

\section{Tropideres Schoenherr}

Tropideres Schoenherr, Isis von Oken, Helft 10: 1135, 1823 (Type-species : Anthribus albirostris Fabricius, by original designation), 
Tropideres cyaneotergum Oda (Photo. n)

Tropideres cyaneotergum Oda, Trans. Shikoku Ent. Soc., 14: 115, fig. 3, 12, 21, 30, 41, 48, 70, 77, 1979 (Matsuyama, Tsushima, Hiroshima ; female).

Male. Antennae as long as those in female and not reaching the base of pronotum. Pygidium perpendicular in position. Venter with 5th ventrite much shorter than 4 th and weakly produced ventrally at tip,

Specimens examined: Hirose, Takahashi City, Okayama Pref., 3 đ 1 우, 21. v. 1975, H. Irie leg.

Distribution: Japan (Honshu, Shikoku, Tsushima).

Tropideres japonicus (Roelofs) (Fig. 12, F, G; Photo. o, p)

Litocerus japonicus Roelofs, Ann. Soc. Ent. Belg., XXII, compt. rend.,: 1v, 1879 (Japon) ; Roelofs, Ann. Soc. Ent. Belg. XXIV: 27, 1880 .

Tropideres japonicus: Sharp, Trans. Ent. Soc. London, 1891: 303. ; 891 (Tokyo) ; Jordan. Novit. Zool., XIX: 140, 1912 (Formosa) ; Oda, Trans. Shikoku Ent. Soc. 14: 118, fig. 14, 23, 31, 42, 52, 60, 68, 79, 1979 (Honshu, Shikoku, Kyushu, Is. Yaku, Is. Amami-Oshima, Okinawa, Formosa, Laos, Tonkin).

Specimens examined: 71 exs. from Kumamoto, Kagoshima, Is. Yaku, Is. Amami-Oshima, Is. Tokunoshima, and Is. Okinawa.

Distribution : Japan (Honshu, Shikoku, Kyushu, Is. Yaku, Is. AmamiOshima, Is. Tokunoshima, Is. Okinawa), Taiwan, Laos, Tonkin.

Note. As already pointed out by Oda (1979), specimens from Taiwan differ in several points from Japanese ones and subspecific name is newly given here for them.

T. japonicus japonicus Roelofs : Pygidium without a row of erect setae along middle line, at most with suberect setae at the center a little behind the middle in male; pygidium in female slightly produced ventrad toward apex ; antemedian, postmedian and subapical bands on elytra whitish at most on 3rd and 5th intervals and subapical band on 3rd intervals, luteous grey on the other intervals. Distribution: Japan (Honshu, Shikoku, Kyushu, Is. Yaku, Is. Amami-Oshima, Is. Tokunoshima, Is. Okinawa).

T japonicus odai subsp. nov.: Pygidium with a row of erect setae along middle line in both sexes ; female pygidium more strongly produced ventrad toward apex; antemedian, postmedian and subapical bands on elytra more whitish. Distribution : Taiwan.

Holotype o (Type No. 2198, Kyushu Univ.), Nanshanchi, Nantou Hs., Taiwan, 16. v. 1971, K. Sakai leg.

Paratypes: 2 우, same data as type ; 1 우, same locality as type, 17. vi. 1970, J. Fukuda leg. 1 우, Sunkang, Taiwan, 31. v. 1965, T. Shirōzu leg.

Tropideres insularis Shibata (Photo. m)

Tropideres insularis Shibata, Ent. Rev. Japan, XVI: 7, pl. 1, fig. 9, 1963 (Is. Amami) ; Oda, Trans. Shikoku Ent. Soc., 14: 117, fig. 13, 22, 33, 44, 50, 58, 69, 78, 1979 (Is. AmamiOshima). 


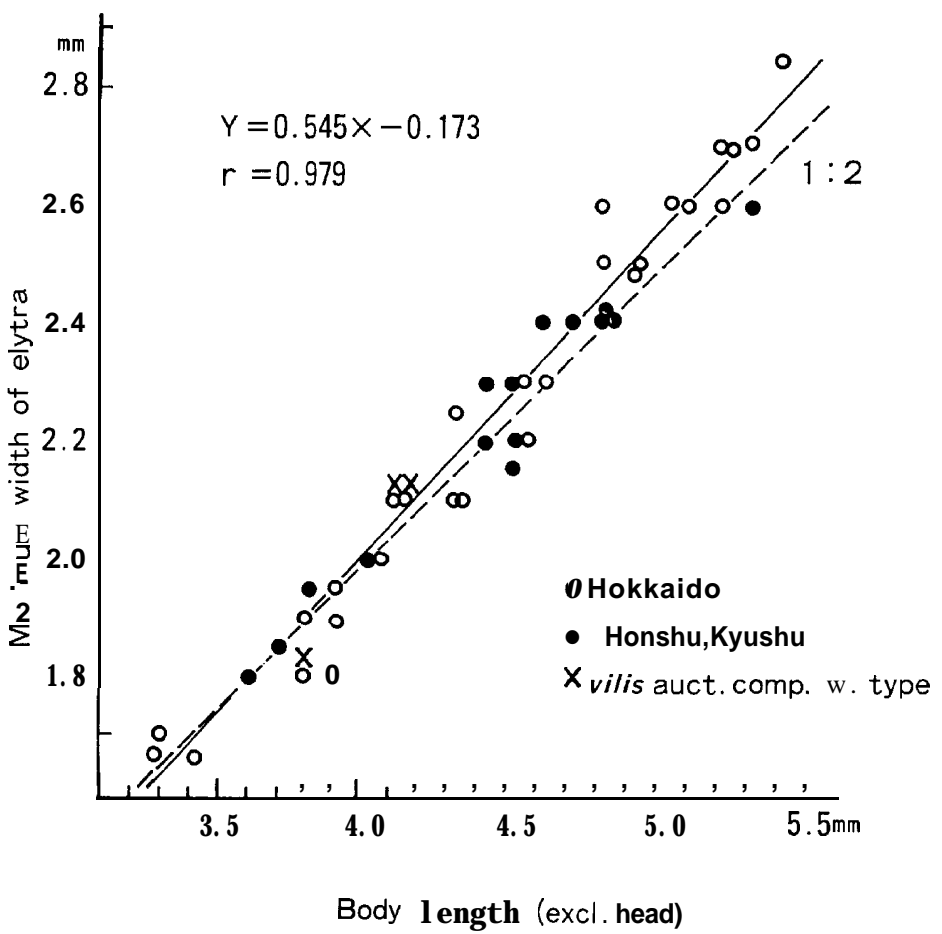

Fig. 13. Tropideres naevulus, the relation between the maximum width of elytra to the body length (excl. head).

Specimens examined : 48 exs. from Is. Amami-Oshima and Is. Tokunoshima.

Distribution: Japan (Is. Amami-Oshima and Tokunoshima).

Tropideres roelofsi (Lewis) (Photo. 1)

Litocerus roelofsi Lewis, Ann. Mag. Nat. Hist., 5(4): 465, 1879 (Nagasaki, Iponmatzu).

Tropideres roel ofsi: Sharp, Trans. Ent. Soc. London, 1891: 303, 1891 (Nagasaki, Kiga, Higo);

Uno, Ent. Rev. Japan, V: 50, p1. 2. fig. 2, 1950; Nakane, Icon. Ins. Jap. : 1257, fig.

3621, 1950; Nakane, Icon. Ins. Jap. col. nat. ed., II: 351, pl. 176, fig. 13, 1963 (Honshu,

Shikoku, Kyushu) ; Oda, Trans. Shikoku Ent. Soc., 14: 119, fig. 4, 15, 24, 35, 46, 55, 57,

80, 1979 (Honshu, Shikoku, Kyushu, Tsushima, China, Formosa).

Specimens EXAMined : 39 exs. from Wakayama, Tokyo, Fukuoka, Ōita, Kumamoto and Kagoshima Prefs., and Tsushima.

Distribution: Japan (Honshu, Shikoku, Kyushu, Tsushima, China (Fukien), Taiwan.

Tropideres naevulus Faust (Fig. 13, Photo. q, r, s)

Tropideres naevulus Faust, Deut. Ent. Zeit., XXXI: 162, 1887 (Chabarofka) ; Schilsky, Käf. Eur., XLIV: 93, 1907.

Tropideres germanus Sharp, Trans. Ent. Soc. London, 1891: 304, 1891 (Buno, Moon Temple, 
Kobe, Nikko, Yuyama, Kashiwagi, Sapporo, Junsai); Nakane, Icon. Ins. Jap. col. nat. ed., II: 352, pl. 176, fig. 21 (Hokkaido, Honshu, Shikoku, Kyushu) ; Seno, Insect fauna of Niigata (ed. Baba) : 82, 1979 (variation) ; Oda, Trans. Shikoku Ent. Soc., 14: 123, fig. 6, 7, 17, 27, 36, 39, 54, 59, 65, 72, 83, 1979 (Honshu, Shikoku, Kyushu, Tsushima) .Syn. nov.

Tropideres vilis Sharp, Trans. Ent. Soc. London, 1891: 305, 1891 (Yezo, Hitoyoshi, Kashiwagi); Oda, Trans. Shikoku Ent. Soc., 14: 119, fig. 8, 18, 25, 32, 45, 49, 62, 66, 71, 81, 1979 (Hokkaido ?, Honshu, Shikoku, Kyushu) .-Syn. nov.

Tropideres yezoensis Oda, Trans. Shikoku Ent. Soc., 14: 121, fig. 5, 16, 26, 34, 43, 53, 61, 67, 73, 82, 1979 (Hokkaido).-Syn. nov.

Specimens examined: 140 exs. from Hokkaido, Aomori, Fukushima, Iwate, Gunma, Tokyo, Yamanashi, Nagano, Shizuoka, Osaka. Okayama, Tottori, Kōchi, Fukuoka, Ōita and Kagoshima Prefs., and Tsushima.

Distribution: Japan (Hokkaido, Honshu, Shikoku, Kyushu, Is. Sado, Is. Hachijo, Is. Tsushima), Siberia,

Note. This species is considerably variable in scaly markings and coloration as already pointed out by Sharp (1891) and Seno (1979). They show a tendency to be whitish on the underside and rostrum from central Honshu northwards to Hokkaido. Some specimens from Tsushima have yellowish to crayish patches instead of grey or white on elytra. Seno also noted the local variation of scaly coloration. The punctuation and shape of pronotum are also variable in considerable extent. T.vilis is nothing but a smaller form with less variegated surface and yezoensis is a northern form of naevulus and many transitional forms are observed in the materials from northern Honshu and Hokkaido.

\section{Key to SPecies of the genus Tropideres from Japan}

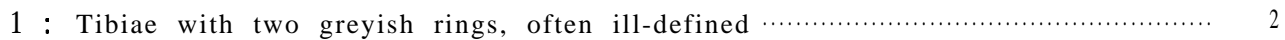

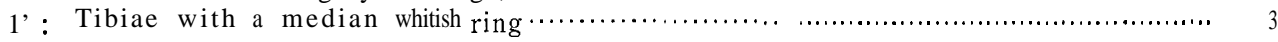

2 : Prothoracic dorsal carina bisinuate, antennae reddish to dark reddish brown Tropideres japonicus (Roelofs)

2': Prothoracic dorsal carina often sinuate, but not angulate at middle, antennae blackish, frons between eyes as wide as or a little narrower than front tibia .Tropideres naevulus Faust

3 : Frons between eyes wider than front tibia, rostrum without carinae, antennae shorter, not reaching the base of pronotum ........... Tropideres cyaneotergum Oda

3' : Frons between eyes much narrower than front tibia, rostrum with a median and a pair of dorso-lateral carinae, antennae at least reaching the base of

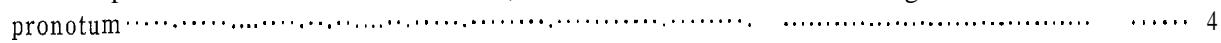

4 : Prothoracic dorsal carina straight, first ventrite visibly smooth, punctures very weak, male without any projection on middle tibia

4': Prothoracic dorsal carina bisinuate, first ventrite coarsely punctate; male middle tibiae with triangular projection ventrally at apex ….. Tropideres roelofsi (Lewis) 


\section{Explanation of photographs}

A. Sintor dorsalis dorsalis Sharp, female ; Fukuoka.

B. Sintor dorsalis intermedius Shibata, female; Tsushima.

C, D, E. Sintoryamawakii sp. nov. C: Holotype, male. D: Paratype, male. E: Paratype, female.

F. Sintor bipunctatus Shibata, female ; Is. Yaku.

G. Asemorhinus nebulosus Sharp, Holotype, male ; Nara.

H. Plintheria caliginosa Shibata, male ; Is. Hahajima.

I. Plintheria variolosa Shibata, female, Is. Amami-Oshima.

J. Endreytes gotoi Shibata, female ; Kumamoto.

$\mathrm{K}$. Cedus insignis Shibata, male; Is. Hahajima.

L. Cedus japonicus Shibata, male ; Taiwan.

M. Sympaector rugirostris Sharp, female ; Is. Yaku.

N. Nessiodocus triodes Jordan, female ; Taiwan.

0 . Nessiodocus repandus Jordan, female ; Is. Yaku.

P. Nessiodocus antennalis sp. nov. paratype, male; Cape Sata.

Q, R. Nessiodocus propinquus Shibata, Is. Okinawa; Q: male. R: female.

S, T. Mucronianus takemurai Nakane. S: Female, T: Male ; Is. Yaku.

U. Androceras flavellicornis Sharp, male ; Okayama.

V. Acorynus latirostris Sharp, type ; Nikko.

W. Acorynus okinawanus sp. nov., paratype, female; Is. Okinawa.

$\mathrm{X}$. Acorynus poecilus Shibata, male; Is. Ishigaki.

Y. Acorynus asanoi Nakane, male ; Is. Yaku.

Z. Litocerus communis Jordan, paratype ; Formosa : Fuhosho.

a. Litocerus communis amamianus Shibata, female ; Is. Amami-Oshima.

b. Litocerus tokarensis tokarensis Nakane, female ; Is. Nakanoshima.

c. Litocerus tokarensis insensibilis Shibata, male ; Is. Yaku.

d. Litocerus kimurai Shibata, female ; Is. Yaku.

e, f . Litocerus multiguttatus Nakane, female. e :Fuji-rindo; f: Mt. Inunaki.

g. Litocerus rufescens Roelofs (=securus Boheman), type ; Nagasaki.

h. Litocerus laxus Sharp (Tropideres), type ; Yuyama. Gonotropis insignis sp. nov., holotype, male; Hokkaido. Gonotropis crassicornis Sharp, female ; Hokkaido.

k. Gonotropis murakamii Oda, male ; Gunma. Tropideres roelofsi Lewis, male; Fukuoka.

m. Tropideres insularis Shibata, male ; Is. Amami-Oshima.

n. Tropideres cyaneotergum Oda, male ; Okayama.

o. Tropideres japonicus Roelofs (Litocerus) ; Japan, Hiller leg.

p. Tropideres japonicus odai ssp. nov., paratype, female ; Taiwan.

q. Tropideres naevulus Faust, type ; Siberia.

r. Tropideres germanus Sharp, type ; Buno.

s. Tropideres vilis Sharp, type; Yezo. 


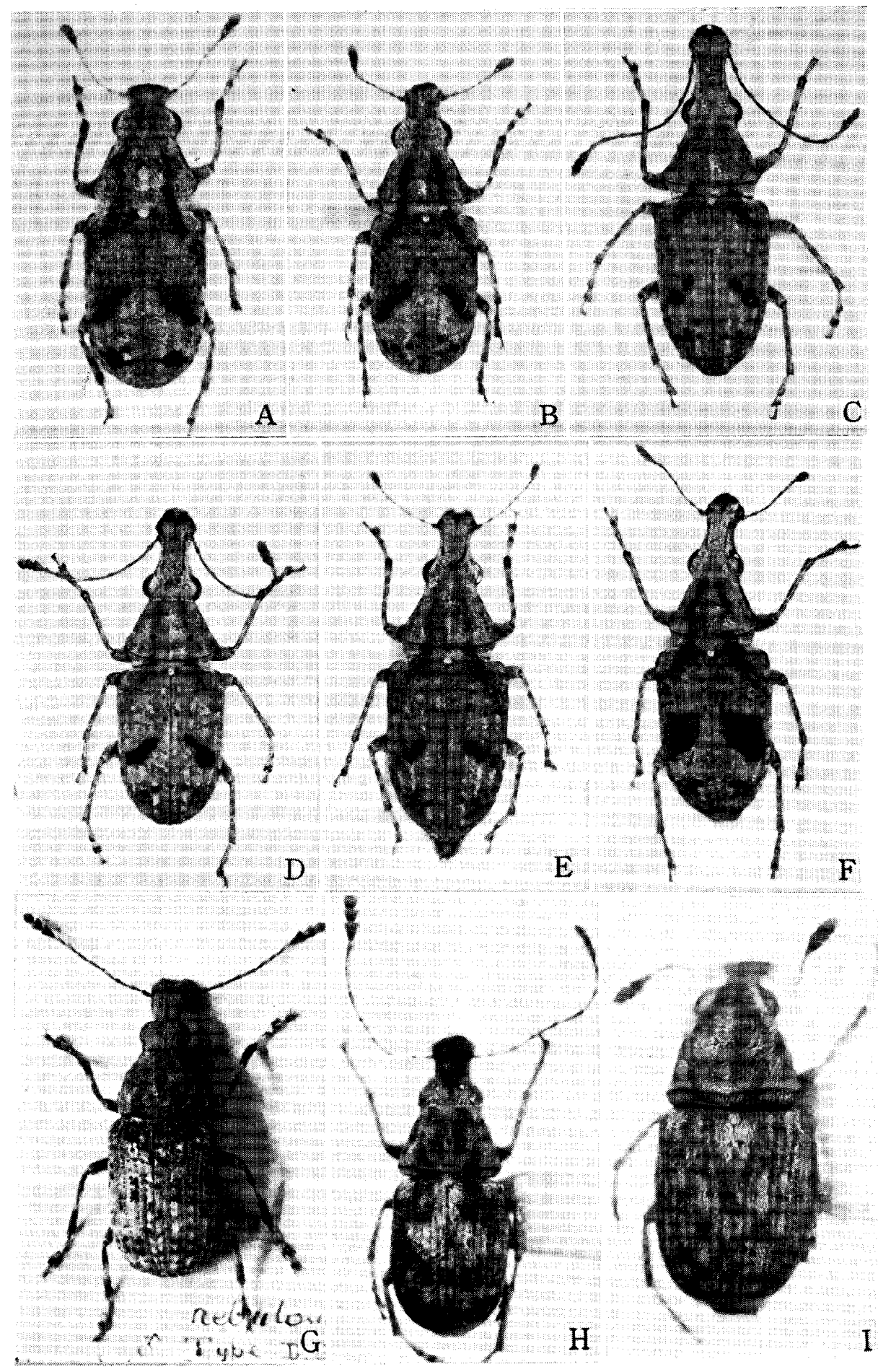



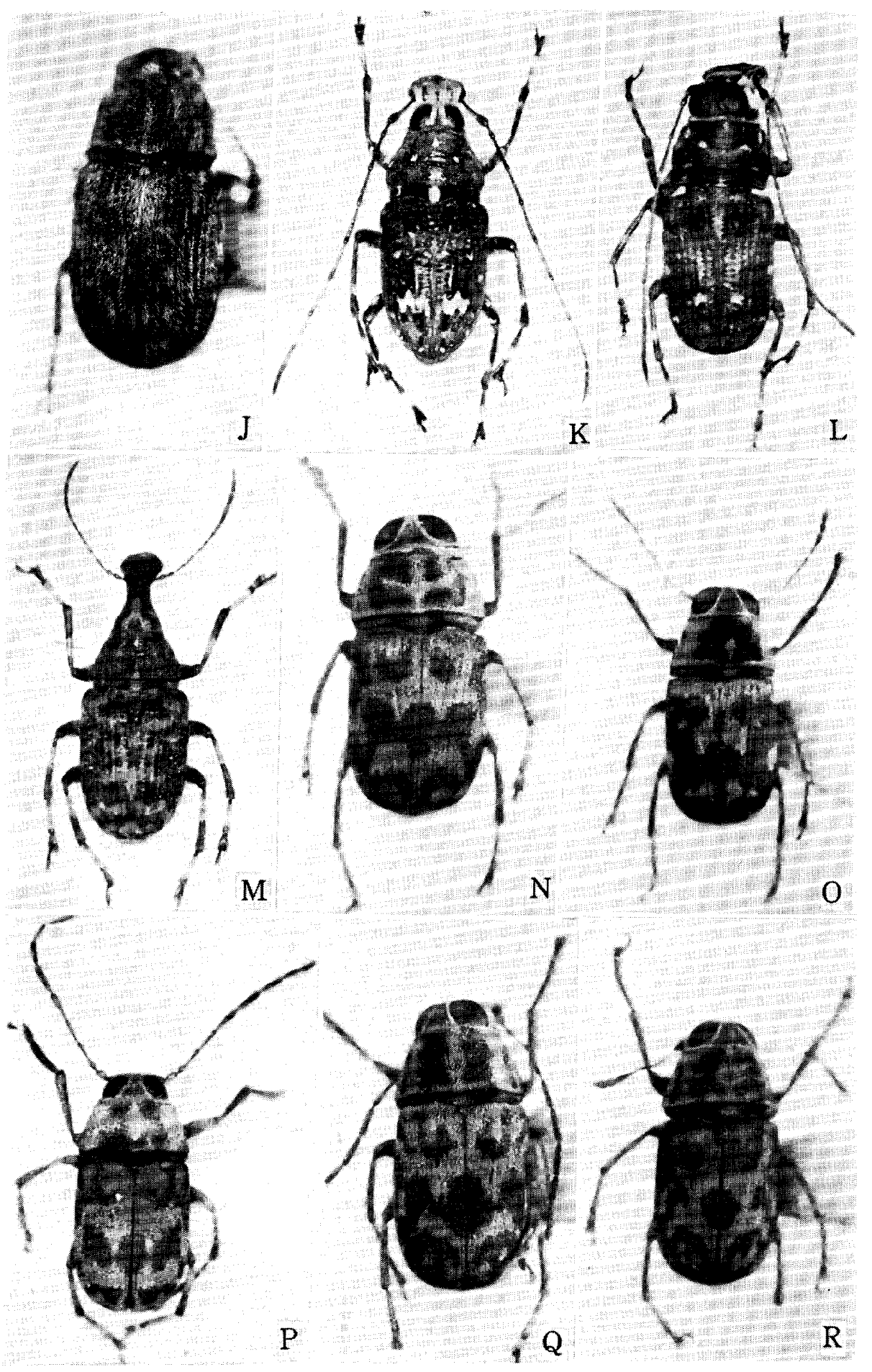
ANTHRIBIDAE OF JAPAN

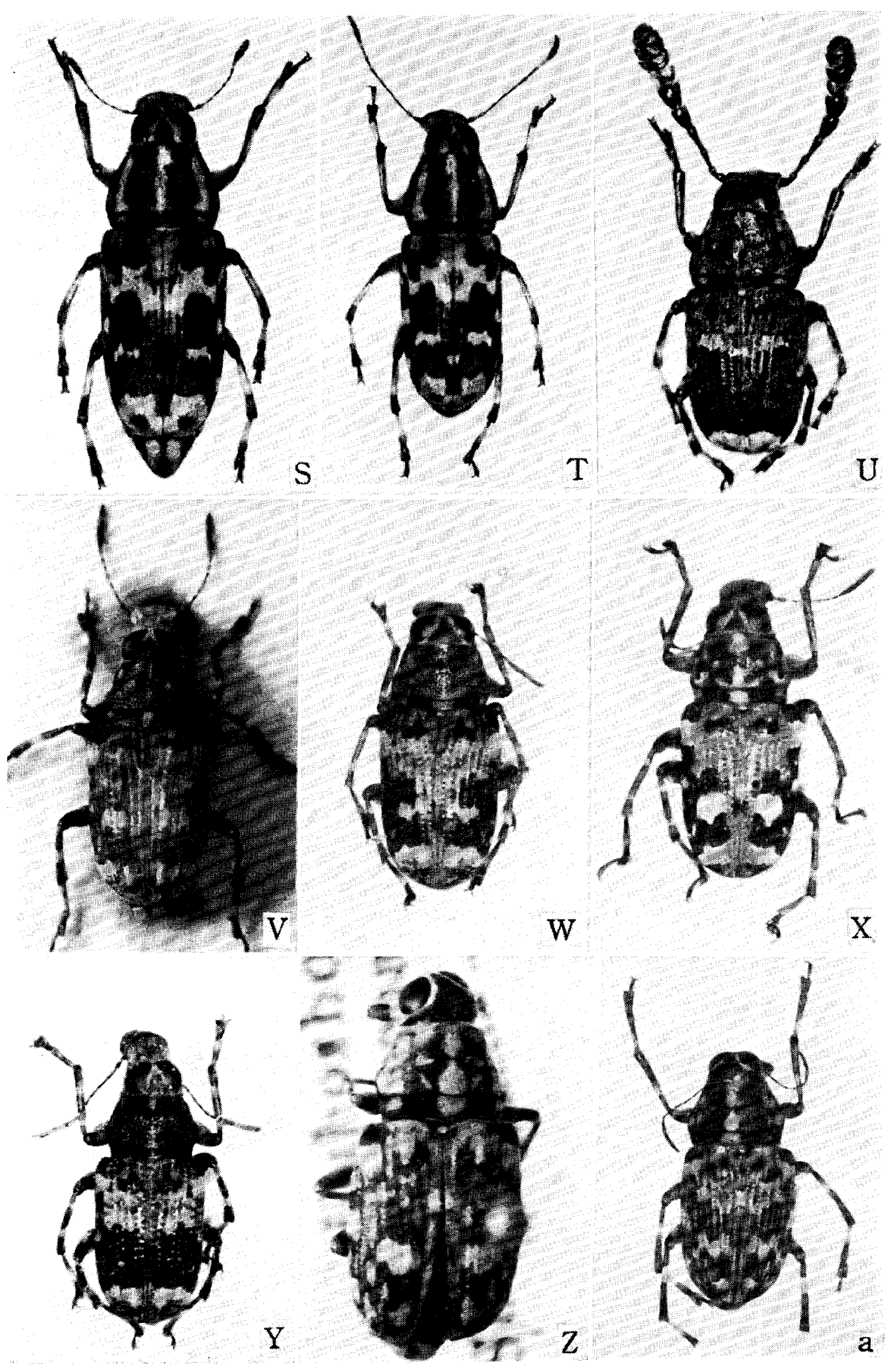


K. MORIMOTO

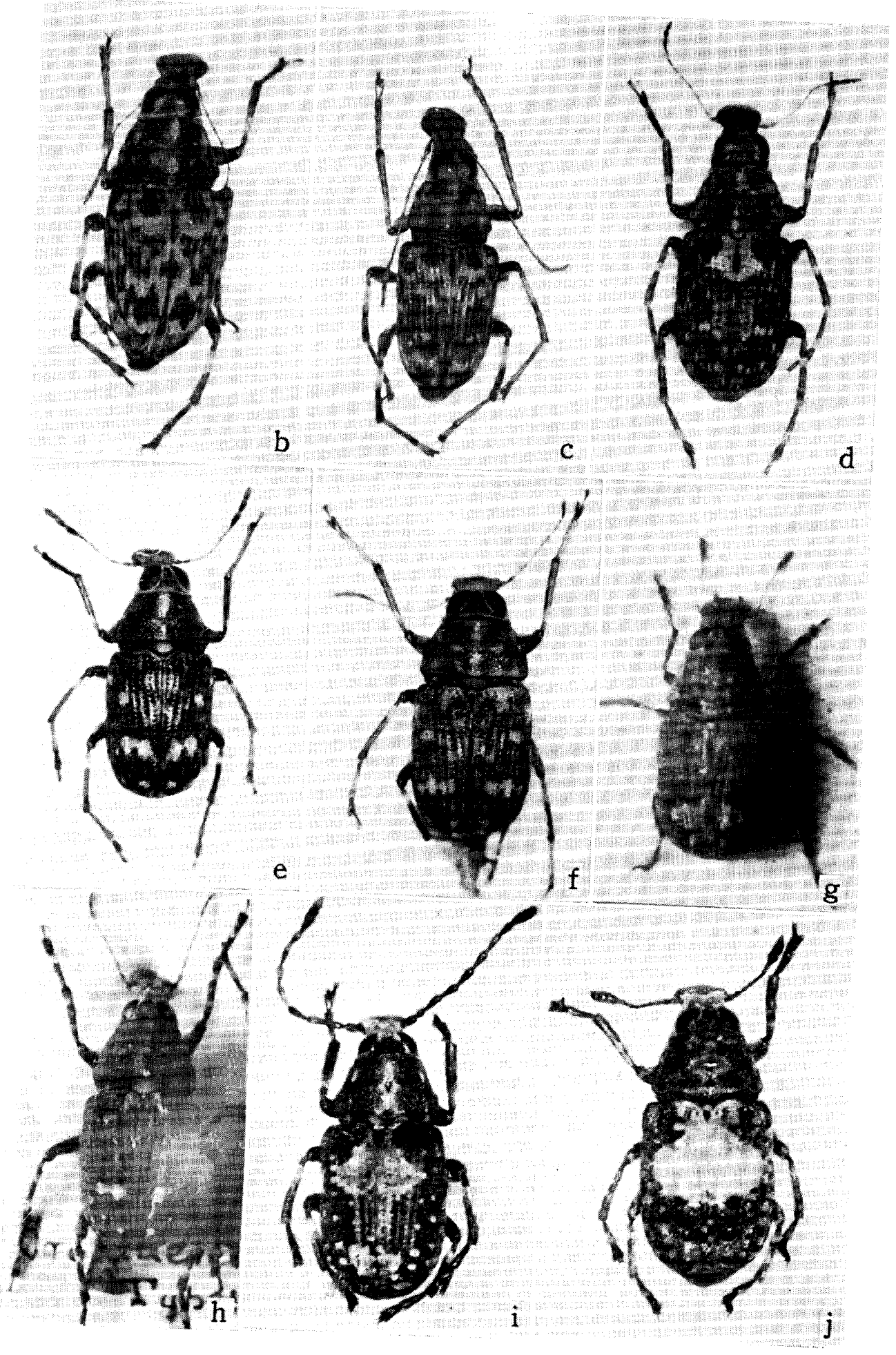


ANTHRIBIDAE OF ${ }_{\text {JAPAN }}$

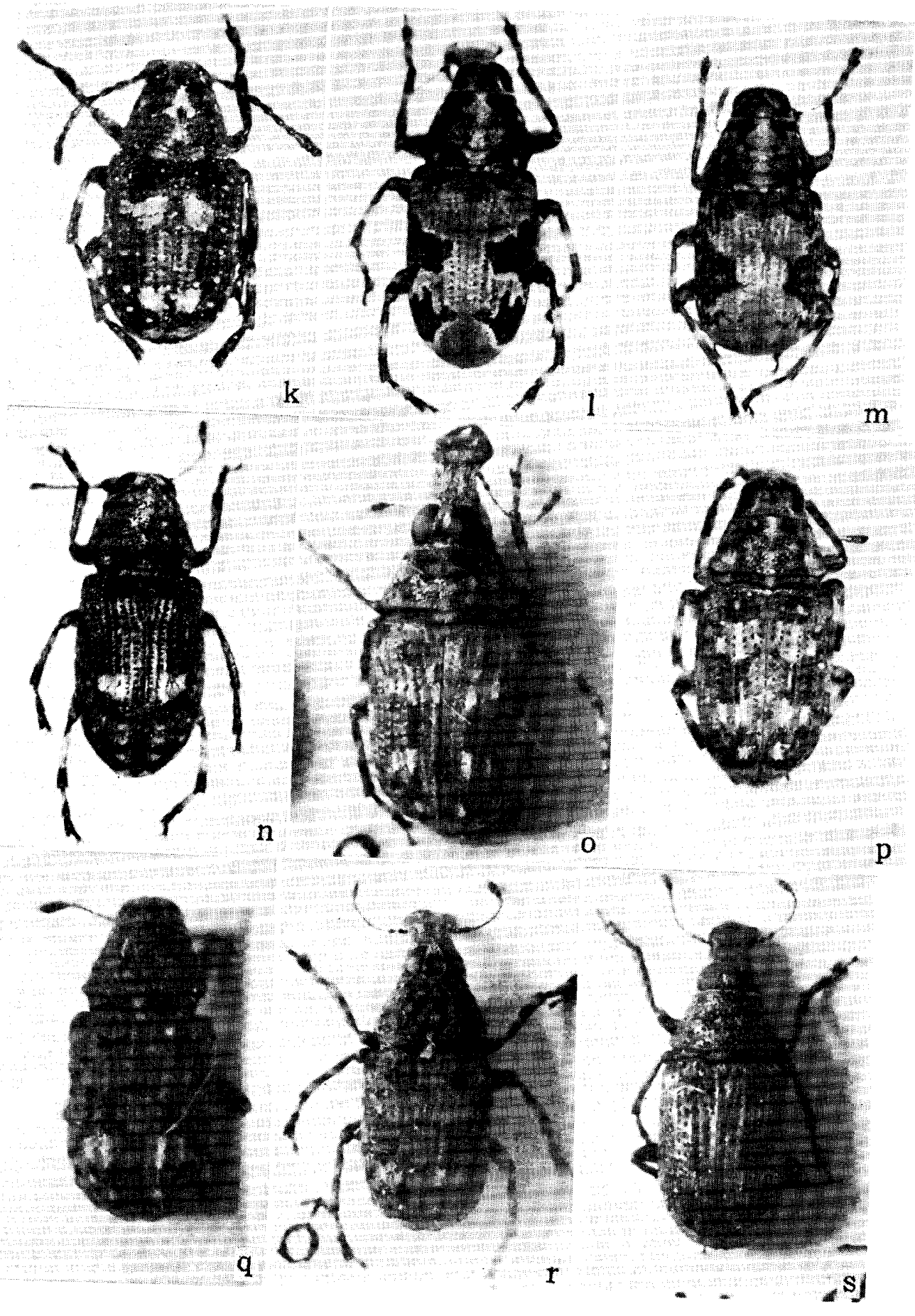

